\title{
Erwin Finlay Freundlich and Testing Einstein's Theory of Relativity
}

\author{
KLAUS HENTSCHEL
}

Communicated by J. D. NorTH

Table of Contents

1. Introduction . . . . . . . . . . . . . . . . . . 143

2. The Early Career of Erwin Finlay Freundlich . . . . . . . . . . 145

3. Freundlich and Einstein from $1911 \ldots \ldots \ldots \ldots \ldots \ldots \ldots$

4. Freundlich's Researches of 1915-16 on the Statistics of Fixed Stars:

Statistical Evidence of Gravitational Redshift? . . . . . . . . . . . 155

5. Freundlich's Solar Eclipse Expeditions: Photographic Evidence of Gravity's

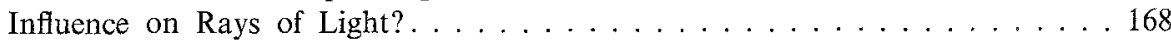

6. Freundlich's Speculations on the Photon-Photon Interaction,

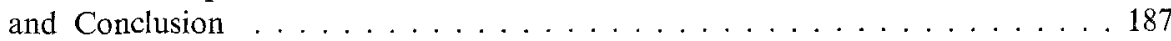

Acknowledgments . . . . . . . . . . . . . . . . . . . . . 192

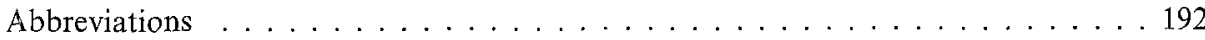

Bibliography . . . . . . . . . . . . . . . . . . . 193

\section{Introduction}

This article covers aspects of the life and career of ERwIN Finday Freund. LICH, the first German astronomer to consider seriously EINSTEIN's theory of relativity and gravitation. In doing so, he made himself so unpopular among his colleagues that nothing less than EINSTEIN's powerful intercession was necessary for him to be able to continue his research on the experimental verification of this theory. From 1917, Freundich was the first full-time employee of the Kaiser-Wilhelm-Institut für Physik which had been established for EINSTEIN in that same year. In 1920, FrEUNDLICH became director of an institute that had been furnished especially for him, informally called the Einstein Tower. Here FREUNDLICH planned to investigate in particular the gravitational redshift in the solar spectrum predicted by EINSTEIN. The background on the funding and the early history of this research station for solar physics, along with its related architectural and sociological aspects, is presented more comprehensively elsewhere $;{ }^{1}$ therefore, following a brief biographical summary of the astronomer

1 See Hentschel [1992]b. 
(in Section 2) and his exchange of ideas with EINSTEIN starting in 1911 (in Section 3), I will concentrate in Sections 4 and 5 on describing two of FreUndLICH's efforts to test the predictions of the theory of relativity which are unconnected to the Einstein Tower, namely, his attempt in 1915-1916 to derive indications of gravitational redshift from fixed-star data (Section 4) as well as his observations with regard to the bending of light in a gravitational field, especially on the occasion of the solar eclipse in Sumatra in 1929 (Section 5).

Both episodes are also interesting from the point of view of philosophy of science, because in both cases unsuccessful attempts at using or analysing anew older data are involved. It is remarkable that in both episodes this strategy failed to test relativity theory, partly because the data had originally been generated for totally different purposes with, for example, quite different criteria for what counts as high-quality photographs of a solar eclipse.

The choice of ERwin Finlay Freundich and his efforts to test the theory of relativity as a topic, might require a short justification, considering that it is shown in the following that FreunduICH's scientific program largely failed, that he suffered a number of setbacks in his career as well, and that he sometimes just had bad luck (as, e.g., with the bad weather on most of his solar eclipse expeditions). For one, Freundich, though today almost forgotten, interacted in his day with a considerable number of renowned scientists, i.e., Haber, Nernst, Bosch, Planck, and naturally, primarily, EINSTeIN; and a lot of new and exciting things are revealed about the last from their correspondence. On the other hand, FREUNDLICH seems to me to be of interest precisely because he is not one of those exceptional apparitions who revolutionized science, but rather a typical, or 'normal' scientist. He becomes for us, in a sense, a kind of "test particle" in that similar to its path, the numerous curves along the course of FREUNDLICH's career reveal the "attractive and repulsive potentials" of the Berlin research environment. Unlike Ernstein, for example, whose total mass was too large, to develop the metaphor further - that is, he was too famous, too idiosyncratic, and otherwise too well protected - for animosities to hamper significantly his activities up to 1933 in any way, the influences of the various powerful cliques of scientists made their full impact on FreUndLICH's course. FreUndLICH's fate tells us something about the different factions comprising the scene of Berlin science, about the 'protective belt' of scientists in defense of Einstein ${ }^{2}$ as well as about the anti-relativists who formed the overwhelming majority not only at the Physikalisch-Technische Reichsanstalt, but also even within the community of Berlin astronomers. It was only in 1933 with the Nazis' 'seizure of power' that a major turning point came about for both EINSTEIN and FREUNDLICH, through forced emigration, which meant an end to their collaboration, even though their relationship had already been soured since 1925 through differences of opinion and personal tensions.

\footnotetext{
${ }^{2}$ See in this regard HentSChel [1990] Section 3.4.
} 
The correspondence between EINSTEIN and FreundLICH was auctioned a while ago ${ }^{3}$ and copies are also in the archive of the Collected Papers of Albert Einstein in Boston, which I was able to examine. ${ }^{4}$ Other letters by FreUndLICH were located in the estates of various scientists with whom he had been in contact, though I was unable to discover the whereabouts of FREUNDLICH's diaries, his private correspondence, etc. However, there is an abundance of documents by and on FREUNDLICH in the archives of several institutions, upon which this study is based: ${ }^{5}$

Main Archive of the Akademie der Wissenschaften, Berlin, of the former GDR, especially files of the Babelsberg Observatory as well as of the Astrophysical Observatory (abbreviated in the following as (AAW)),

Mary Lea Shane Archives of the Lick Observatory, Santa Cruz (ALO),

Archive for Scientific Philosophy in the $20^{\text {th }}$ Century, Pittsburgh (ASP),

Collected Papers of Albert Einstein, Boston University (Editorial Archive) or Hebrew University of Jerusalem (Original EINSTEIN estate) (CPAE),

Library of the Eidgenössische-Technische Hochschule, Zurich, especially the estate of Hermann Weyl and Wolfgang Pauli (ETH),

Royal Astronomical Society, London (RAS).

The provenances are referred to in the following in their abbreviated form (see above) followed by the call number.

\section{The Early Career of Erwin Finlay Freundlich}

Six years Einstein's junior, Erwin FinLAy FreUndLich ${ }^{6}$ (1885-1964) was the son of a German manufacturer, Friedrich Philipp Ernst Freundlich, and his English wife, Ellen Finlayson from Cheltenham, and was born in Biebrich on the Rhine. Freunduch's grandmother was a practising Jew; however, her son converted to the Protestant faith at the time of his marriage, and all of their seven children were baptized and brought up as Protestants. The oldest son,

${ }^{3}$ It is now a part of the Piermont Morgan Library, New York; for more on this see International Herald Tribune, 26 March 1992, p. 20.

4 The FREUNDLICH-EINSTEIN correspondence up to 1914 has just appeared in Volume 5 of The Collected Papers of Albert Einstein: see KLEIN et al. (Eds.) [1993], with the remaining letters to appear in subsequent volumes.

5 For a more extensive list of archival material, see HENTSCHEL [1992] b p. 14.

6 On Freundlich see, e.g., v. Klüber [1965], Forbes [1972], PYENSON [1974], pp. 313-337, [1985] pp. 228-238, BATTEN [1985], HENTSCHEL [1992]b. I am indebted to his nephew, Mr. WINFRIED F. FREUNDLICH in Wiesbaden, for personal information on FREUNDLICH. For portrait photos, see Figure 2. 
Herbert Max Freundlich (1880-1941), is particularly noteworthy as an important colloid chemist. ERwIN had a normal education - technical secondary school (Realgymnasium) to the third year (Quarta); after that he earned his certificate at another highschool for graduation in the humanities (Abitur) at Easter, 1903. A half-year of voluntary service at the "Vulkan" shipping wharf in Stettin inspired the young man to study ship-building. He abandoned this subject, however, in the autumn of 1905 in order to study mathematics and astronomy in Göttingen. Under the guidance of the famous mathematician and administrator of science FeLix KLEIN ${ }^{7}$ (1849-1925), he completed his doctoral dissertation on January 26, 1910 on functional analysis, entitled "Analytische Funktionen mit beliebig vorgeschriebenem, unendlich-blättrigem Existenzbereiche".

Through KLEIN's intercession he received a position at the end of July at the Königliche Sternwarte, an observatory in Berlin, as assistant to the director, Karl Hermann Struve ${ }^{8}$ (1854-1920). An unverified but nevertheless plausible anecdote here is that FREUNDLICH complained to KLEIN upon receiving this appointment, since he felt he did not know enough about practical astronomy; whereupon KLEIN's categorical response was: "You did not come to the university in order to learn everything, but to learn how to learn everything. You will go to Berlin." "9 In fact, Felix KLeIN was very interested in a close interrelation of mathematics and physics or the other sciences - he himself, along with many of his students, made important contributions to both disciplines and their peripheral fields. ${ }^{10}$ "Physics is too important to be left to the physicists" ("Die Physik ist zu wichtig, als daß man sie den Physikern überlassen darf"); this famous statement by DAVID HILbERT is also appropriate (when 'physics' is replaced by 'astronomy') in justifying the recommendation of the mathematically educated Freunduich to the Berlin observatory. Nevertheless, the move for FreundLICH from Göttingen to Berlin must have been like a plunge into cold water: he was immediately involved in the routine work $^{11}$ of the observatory (i.e., compiling a zone catalog of pole stars and photometric observations as well as work using a meridian circle), which was not particularly stimulating. ${ }^{12}$

${ }^{7}$ For more on KLEIN, see, e.g., ToBIES [1981], Rowe [1989] as well as their references.

8 STRUVE came from a family of astronomers and succeeded FörSTER in 1904 as director of the Berlin observatory. For more on STRUve, see e.g., Courvorser [1920], DYSON [1921].

9 "Sie sind nicht zur Universität gekommen, um alles zu lernen, sondern um zu lernen, wie man alles lernen kann. Sie werden nach Berlin gehen." See BATTEN [1985] p. 33 .

10 See, for example, PYENSON [1974], [1985] with particular attention to relativity theory as well as Rowe [1989] and SIGURDSSON [1991] on the Göttingen 'Denkkollektiv'.

11 See, i.e., EINSTEIN to STRUve, 2 Feb. 1916, cited on p. 35.

12 This information on FrEUNDLICH's early development is based in part upon a curriculum vitae he had written at the Babelsberg Observatory (AAW), folder 64, 
An inquiry by the Prague astronomer Leo Wenzel Pollak ${ }^{13}$ in August 1911 on behalf of the young professor of theoretical physics at the German University in Prague, AlBERT EINSTEIN, brought his attention to the question of how EINSTEIN's new theory introduced in his paper "On the Influence of Gravitation on the Propagation of Light" ${ }^{14}$ could be tested by means of astronomy. ${ }^{15}$ Ernstein was of the opinion that two of his predictions, what was called the redshift of spectral lines and the bending of light in a gravitational field, "urgently need verification through astronomy", but he doubted that the predictions, "except in the case of the sun, could have any success whatsoever", because of their dependence on the magnitude of the gravitation potential $(\phi \sim m / R) .{ }^{16}$

The significance of the two physical effects of relativity theory already mentioned is as follows: ${ }^{17}$ Unlike classical physics, Einstern's theory of space, time, and gravitation leads to the conclusion that the presence of masses should have a certain influence on the propagation of light and on the space-time structure indicated by light propagation. ${ }^{18}$ EINSTEIN predicted that the larger the masses are, and the closer the passing light is to these centers of mass, the greater is the influence. The largest mass with which this could still be observed reasonably well with the means available at that time, was that of the sun as the central body of our planetary system. The light deflection effect proposed by EINSTEIN, which rays of light originating from remote fixed stars experience as they pass by the rim of the sun, was already partly familiar from the assumption EINSTEIN had argued since 1905 that energy and mass are physically equivalent. Since the end of the $19^{\text {th }}$ century it had been known that light transports energy; in 1905, EINSTEIN had shown the energy-mass equivalence. Thus, it should also behave like a current of particles of the mass $m=E / c^{2}$ (with $c$ as velocity of light); this means that a stellar ray of light should be slightly deflected from its course as it passes near the surface of the sun, like passing comets. After 1913 EINSTEIN modified this concept of light deflection, to

sheets 1-2), and also in part upon a resumé in his dissertation of 1910: FreundLICH [1911].

13 Born in 1888; demonstrator at the Institute for Cosmological Physics at the German University in Prague, where EINSTEIN had also been teaching since 1911.

14 EINSTEIN [1911]a, which constituted what he called his Prague theory.

15 Pollak to Freundlich, 24 Aug. 1911, (CPAE), call no. 11 181. See also Clark [1973] pp. 120f.

16 "einer Nachprüfung durch die Astronomie dringend bedürfen" "ausser bei der Sonne, von irgend welchem Erfolge begleitet sein könnten." Ibid.

17 For more information on the experimental consequences of his theory, see among others Forbes [1963], EARMAN \& Glymour [1980]a, b, HentSChel [1992]a, [1993]a and references therein, as well as, e.g., FREUNDLICH's overviews [1916], [1919]b, [1955]a.

18 The physicist has no alternative but to define straight lines for astronomical magnitudes according to the "straight" course of rays of light. 


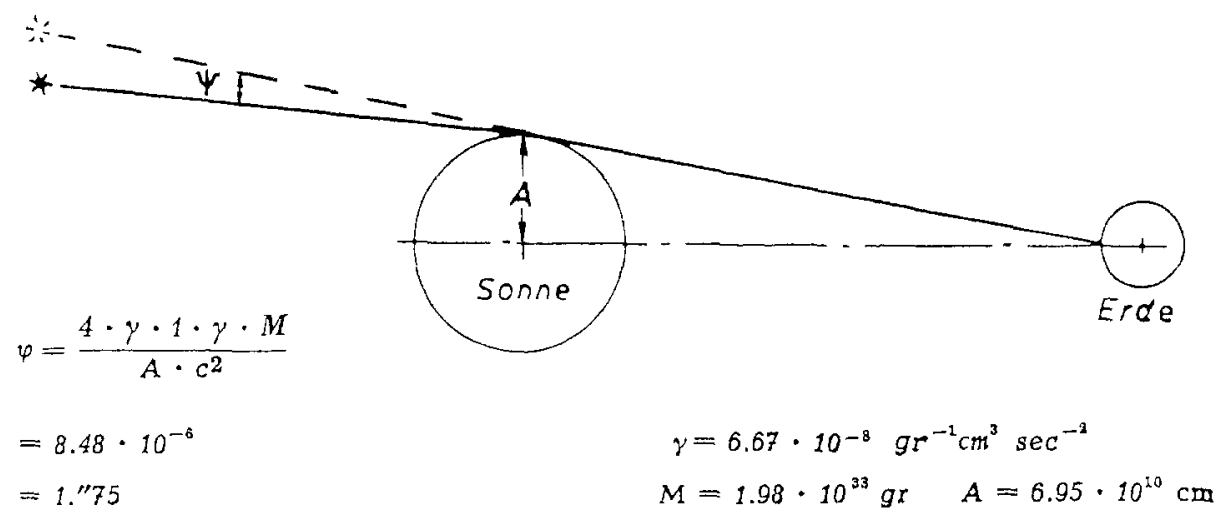

Figure 1. Diagram of the deflection of light within the gravitational field of the sun. The drawing grossly exaggerates the effect. Figure from GrOTRIAN [1952] p. 84.

conform it to the changed space-time structure near large masses, or in curved space. This deflection was disappointingly small: $0^{\prime \prime} .85$, that is, smaller than one arc second for Ensstern's theory of 1911, and $1^{\prime \prime} .75$ for the theory of $1915-16,{ }^{19}$ each for rays passing the sun tangentially - as the distance $r$ increases, the effect decreases by $1 / r$ (see Figure 1 ).

Not only the structure of space but also measurement of time is influenced, according to EINSTEIN, by the presence of mass. Clocks and periodic processes in general slow down when they are brought within the proximity of a mass. Gaseous atoms which exhibit a specific and exactly determined eigenfrequency, which is also present in the light they emit or absorb and visible as sharp lines in its spectrum, can also be looked upon as a periodic time keeping device, which perform not sixty but millions of oscillations per minute. It was already known from analysing the solar spectrum that many elements exist in the sun which are found also on earth. Using this fact, EInstern hoped that when comparing the solar spectrum very precisely against laboratory spectra, the absorption lines in the solar spectra would seem shifted toward the lower frequencies as against their terrestial counterparts, i.e., toward the red end of the spectrum as a result of the sun's greater mass.

Yet this effect, known as the redshift of spectral lines within a gravitational field is also minute: Detecting the relative shifts of less than a hundred-thousandth $\left(2 \cdot 10^{-6}\right)$ was at the very limit of the achievable precision in spectroscopic measurements of the time, though Einstein managed to find a few indications of such redshifts in the solar spectrum in the scientific literature. ${ }^{20}$

19 See also EINSTEIN [1911], [1912], [1915]a-c, [1916]b, [1917] and [1920] as well as Section 4 for a brief survey of the development of the general theory of relativity.

20 See, for example, EINSTEIN [1911]a p. 905; and also HentSCHEL [1992]a, b. 
Because both effects were so minute, it is no wonder that EINSTEIN was at first practically ignored by astronomers; there being only one exception in Germany: Erwin F. Freunduich! However, as Freunduch himself writes in a resumé around 1915, he was able to work only in his "hours of free time" on his "analyses of a theoretical nature" specifically to "test modern physical theories by astrophysical means". ${ }^{21}$ Nevertheless from 1913, his research efforts were no longer concentrated upon the routine tasks for which he had been originally employed at the observatory, but rather upon tackling the more inspiring various consequences of EINSTEIN's theories relevant to astronomy. In contrast to other astronomers in Berlin and elsewhere, FreunduICH was immediately drawn to EINSTEIN's theories, precisely because of his more liberal training at Göttingen. ${ }^{22}$

\section{Freundlich and Einstein from 1911}

FreUndLICF must have responded immediately to PolLaK's initial inquiry, almost as if he had been waiting for such a diversion to free him at last from the endless columns of numbers from his meridian observations. But EINSTEIN also was delighted with Freunduich's prompt reaction. The Prague Ordinarius wrote to the lowly assistant in Berlin:

\section{Dear Colleague!}

Thank you very much for your letter, which naturally interested me greatly. I would be personally very pleased if you took on this interesting question. ${ }^{23}$

FREUNDLICH brought forward the possibility of inspecting old photographs of solar eclipses to detect the apparent small shifts of position of the fixed stars which EINSTEIN had predicted. ${ }^{24}$ In response EINSTEIN expressed again his continued interest in the results of this test:

21 "in den Stunden freier Zeit", "Untersuchungen theoretischer Natur", "Prüfung moderner physikalischer Theorien auf astrophysikalischem Wege". (AAW), Babelsberg Observatory, folder 64, sheet 2.

22 PYENSON [1974] stresses that FREUNDLICH's education at Göttingen places him in the same rank with MINKOwSKI, F. KLEIN and HILBERT, who all had shown interest in EINSTEIN's theories. Unlike the mathematicians from Göttingen, however, FREUNDLICH constantly stressed the experimental aspects in his representations of relativity theory.

23 "Hoch geehrter Herr Kollege! Ich danke Ihnen herzlich für Ihr Schreiben, das mich natürlich sehr interessierte. Es ist mir sehr lieb, wenn Sie sich dieser interessanten Frage annehmen." EinsteIn to FreundLich, 1 Sept. 1911, (CPAE), call no. 11 199, quoted from KLEIN et al. (Eds.) [1993].

24 Solar eclipse photos also show background stars, of which the closest to the sun most clearly exhibit the effect EINSTEIN predicted. This is discussed in detail in Section 5 of this paper. 

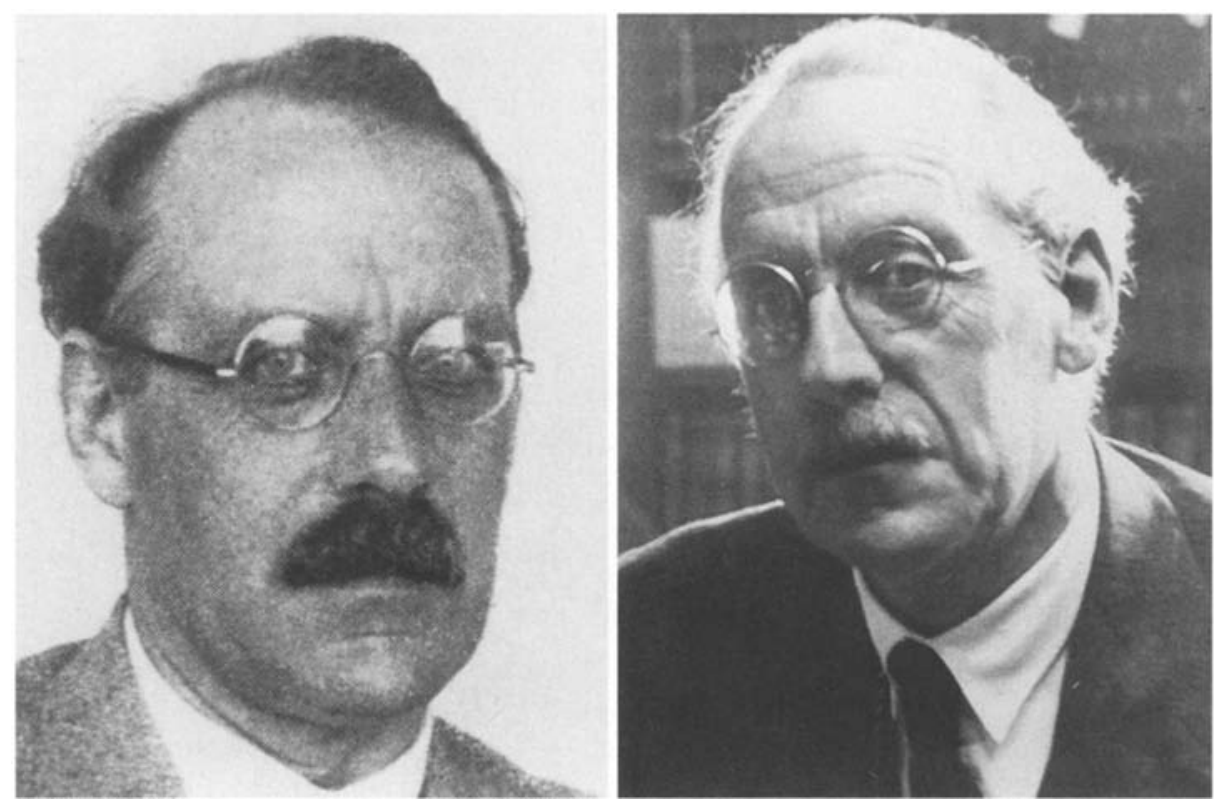

Figure 2. Two portraits of FreUNDLICH (ca. 1937 and ca. 1960). Both photos from the International Portrait Catalogue of the Archenhold Observatory.

I am extremely pleased that you have taken on the question of light deflection with such enthusiasm and am very curious what the examination of the available plates will yield. This is a very fundamentally important question $\left[{ }^{25}\right]$. From the theoretical standpoint, it is quite probable that the effect really exists. ${ }^{26}$

The existence of light deflection was "fundamentally important" to EINSTEIN, because his special theory of relativity of 1905 implied the equivalence of energy and mass $\left(E=m c^{2}\right)$. Since light also transports energy, it also should exhibit the properties of inertia, just as do masses in a gravitational field. EINSTEIn's paper of 1911 presented this idea in a systematic form and for the first time offered an estimate of the size of this effect of gravitational fields on the propagation of light passing close by the sun's rim emitted by fixed stars (see

25 Namely, whether light is subject to gravitation or not.

26 "Ich freue mich ausserordentlich darüber, dass Sie sich der Frage der Lichtkrümmung mit so grossem Eifer annehmen und bin sehr neugierig, was die Untersuchung des vorliegenden Plattenmaterials ergeben wird. Es handelt sich um eine Frage von ganz fundamentaler Bedeutung. Vom theoretischen Standpunkt aus besteht eine ziemliche Wahrscheinlichkeit dafür, dass der Effekt wirklich existiert." EINSTEIN to FREUNDLICH, 8 Jan. 1912, (CPAE), call no. 11 202, quoted from KLEIN et al. (Eds.) [1993]; see also the letter dated 1 Sept. 1911, (CPAE), call no. 11199. 
p. 4 and Fig. 1). The possibility of directly verifying this prediction consisted in waiting for an eclipse of the sun and then exactly measuring the position of fixed stars closest to the darkened solar disk. But solar eclipses happen only rarely, and favorable conditions for observing them usually come about only in remote regions of the globe, which make necessary special, extravagant, and costly expeditions. This explains FREUNDLICH's initial idea of consulting material brought back from earlier solar eclipses. When it turned out that all of the plates available in Potsdam were completely inadequate for his purposes (see below), FreundLICH wrote to the most important centers of astronomy throughout the world, asking for good reproductions of glass plates of earlier photographs of solar eclipses. His request to WILLIAM Wallace CAMPBELL ${ }^{27}$ (1862-1938) of the Lick Observatory, dated 25 November 1911 has been preserved:

I apply to you on account of a question of sur[e]ly high scientific interest, in which I depend from the kind support of astronomers, who posses[s] eclipse-plates, if I shall hope to get any results. The modern theory of relativity of Mr. EINSTEIN predicts an influence of any field of gravitation upon light passing near to the sun. The gravitation would have according to the investigation of Einstein the effect of deflecting the ray of the star, and Mr. Einstein asked me, if I would try to proof his results by observations. [...].

Now eclipse-plates of the sun showing at the same time a few stars are the only material to be used till now, and I would be very much obliged to you for your kind support to get such plates. A few days ago I had the opportunity to talk to Mr. Perrine at Cordoba on his way through Berlin and he gave me the advice to apply to you on account of this question. ${ }^{28}$

When FREUNDLICH had still not received a response after many weeks, he repeated his request to California, whereupon he received an answer from 13 March 1912, in which CAMPBELL greatly regretted the loss of his first letter in the post and assured him that he would be glad to be of assistance to his research project. ${ }^{29}$ High-quality glass-plate reproductions actually were sent to him of photographs taken during the solar eclipses of 1901 in Sumatra, 1905 in Spain and 1908 on Flint Island, as well as comparison photos of the stellar background. The most recent solar eclipse in particular had a back-drop of many hundreds of fixed stars. However, all the plates made at earlier expeditions for different purposes had four serious drawbacks:

27 On Campbell see, for example, Dyson [1939] and CRelinsten [1983].

28 Freundlich to W. W. Campbell, 25 Nov. 1911; (ALO) (Spelling original). C. D. PERRINE, from 1909 director of the Argentinian State Observatory, was inspired by FREUNDLICH in 1912 to make a solar eclipse expedition to Brazil himself, but was unsuccessful because of rain; see PERrine [1923], STAChel [1986] p. 226. Crelinsten [1983] pp. 12ff. covers other contacts of FREUNDLICH.

29 CAMPBell to Freundlich, 13 Mar. 1912, (ALO): "we have [read] Einstein's paper $[\ldots]$, and we shall be glad to assist you as far as possible in testing the question." 
1. Only very few of the plates had the sun in the middle of the photograph rather than at the edge;

2. The timing of the exposure had been set to the solar corona, not to the distant and dimmer fixed stars for which 40-60 sec. rather than 4-6 sec. were needed;

3. The guiding adjustments made during exposure were set to accommodate for the sun's motion, rather than for the fixed stars' rate in the background; ${ }^{30}$

4. It was impossible to investigate any contractions that the photoplate may have experienced during exposure (determined by a sudden drop in temperature, for example). ${ }^{31}$

FreUnDLICH soon had to give up hope of being able to make use of existing plates for finding evidence of light deflection in the gravitational field of the sun: distortions from the camera lens right at the edge of the exposures as well as blurring of the stars' locations as a result of training the camera at an inappropriate speed made this completely impossible. ${ }^{32}$ FreunduICH reported his negative results in the journal Astronomische Nachrichten of 1913:

With the help of an instrument by Toepfer (Potsdam), which Prof. K. Schwarzschild kindly made available to me, I began first of all to measure a plate from the Smithsonian Institution [...]. I measured the right-angled coordinates of all the stars on the plate near the sun. But since the plate was neither sufficiently centered nor sharply focussed and the stellar images as a result very blurred, there turned out to be such big discrepancies in the settings of the stellar images on the different days, that I had to give up using this plate. But it soon became apparent from all the exposures, even the very valuable ones from the Lick Observatory, which had all simply been produced for completely different purposes, primarily for discovering intramercurial planets, that the inadequate sharpness of the stellar images made any successful measurement of the plates illusory [.. . . I have therefore delayed investigating the whole question until really usable material is available $[\ldots]^{33}$

${ }^{30}$ See, for example, CAmpbell to Freundlich, 6 June 1912, (ALO), p. 2: "For an adequate treatment of the problem which you have in hand, plates should be taken with the sun central, and the cameras should be rated to a stellar rate instead of the solar rate, as was the case in all these eclipse plates".

${ }^{31}$ In later expeditions comparison photographs of the same region of the sky were taken, among others, for this purpose with the same instruments before or after the eclipse. On the contraction problem, cf., e.g., Ross [1920].

${ }^{32}$ See FreUndLICH [1913] as well as, for example, CAMPBell to Freunduich, 6 Mar. 1913, (ALO), p. 1: "Your experience with the eclipse plates is about what we had expected: not only is the sun's image near the edge of the plate, but the aberrations of the camera lens at the edge of the plate are unavoidable; and, further, the clock was regulated to follow the sun and not the stars".

33 "Mit Hilfe eines Meßapparates von Toepfer (Potsdam), den mir Prof. K. Schwarzschild in liebenswürdiger Weise zur Verfügung stellte, begann ich zuerst eine Platte der Smithsonian Institution [...] auszumessen. Ich maß die rechtwinkligen Koordinaten aller Sterne auf der Platte in der Nähe der Sonne. Da aber die Platte ungenügend scharf zentriert und fokussiert war, die Sternbilder infolgedessen sehr verwaschen waren, ergaben 
When EINSTEIN heard of the inappropriateness of the older data for their purposes, he wrote to FrEUNDLICH:

Thank you very much for your detailed report and for your unusually keen interest in our problem. It is a great shame that the new available photographs are not sharp enough for such a measurement. ${ }^{34}$

Even though FreundLICH could not produce from one day to the next a verification of his theory, so to speak out of thin air, as EINsTEIN had perhaps originally hoped, he nevertheless did perform an important service. Since, through his references to the astronomical relevance of EINSTEIN's Prague theory in professional journals such as in the Astronomische Nachrichten, ${ }^{35}$ FreundLICH was the first to bring it to the attention of the German community of astronomers, well in advance of DE SITTER, who achieved the same thing for the English-speaking readers of the Monthly Notices of the Royal Astronomical Society with his synopsis paper of 1917. EINSTEIN recognized this publicity as indispensable toward the general acceptance of his theory following the appearance of FreUnduich's first publication in German, in which he solicited the collaboration of his colleagues in testing ErNSTEIN's predictions. In a letter to his "hoch geehrter Herr Kollege", at that time, the lone advocate within the ranks of professional astronomers in Germany, EINSTEIN writes:

Thank you very much for your interesting letter. It will be thanks to your diligence if the important issue of the deflection of rays of light now begins to interest astronomers as well. ${ }^{36}$

sich derartig starke Verschiedenheiten in den Einstellungen der Sternbilder an verschiedenen Tagen, daß ich die Verwendung dieser Platte aufgeben mußte. Es zeigte sich aber bald, daß auf allen Aufnahmen, auch auf den sehr wertvollen des Lick Observatory, die eben alle zu ganz anderen Zwecken, hauptsächlich zur Auffindung intramerkurieller Planeten gewonnen waren, die ungenügende Schärfe der Sternbilder eine erfolgreiche Ausmessung der Platten illusorisch machte. [...]. Ich habe darum die Untersuchung der ganzen Frage verschoben, bis wirklich brauchbares Material vorliegt [. . . ." FreUndLICH [1913] col. 371; on SCHWARZSCHILD see footnote 86.

34 "Ich danke Thnen herzlich für Ihre ausführlichen Nachrichten und für das ungemein lebhafte Interesse, das Sie unserem Problem entgegenbringen. Es ist ungemein schade, dass die bisher vorliegenden Photographien nicht scharf genug sind für eine derartige Ausmessung." EINSTEIN to FrEUNDLICH, 27 Oct. 1912, (CPAE), call no. 11 205-1, quoted from KLEIN et al. (Eds.) [1993].

35 See FreUndLICH [1913]; compare against FreUndLICH [1914]c.

36 "Ich danke Ihnen herzlich für Ihren interessanten Brief. Ihrem Eifer ist es zuzuschreiben, wenn die wichtige Frage nach der Krümmung der Lichtstrahlen nun auch die Astronomen zu interessieren beginnt." EINSTEIN to FrEUNDLICH, Mid-August 1913, (CPAE), call no. 11 203-1, quoted from KLEIN et al. (Eds.) [1993]; see also the almost identical wording in a later letter of the same month (CPAE), call no. 11 204, quoted KLEIN et al. (Eds.) [1993]: "Es freut mich sehr, dass es Ihnen gelingt, für unsere Frage nach einer Krümmung der Lichtstrahlen so grosses Interesse wachzurufen." 
Through his commitment to the experimental testing of relativity theory, FREUNDLICH had become EINSTEIN's mouthpiece among astronomers; through him, EINSTEIN was able to win the attention of astronomers to the relevance of his theory to precision measurement within their field. This explains the tenacity with which EINSTEIN pressed FREUNDLICH to look for possible astronomical tests of the general theory of relativity, even when the relationship between the two men had already noticeably cooled (see p. 37). The often so difficult recruitment of experimenters by theorists to test effects predicted by their new theories had been a complete success in FreunduCH's case-FreundLICH's own papers, in particular the semipopular overview article for Die Naturwissenschaften of 1916, which in the same year also appeared as a slender little volume through the publisher JuLIus SpRINGER and was later also translated into English and French, show that FREUNDLICH had become completely conversant with ErnsteIN's gravitation theory by this time.

The experimental basis of Einstein's gravitation theory has thus not yet progressed very far. If today the theory can nevertheless already lay claim to general acceptance, then this has its justifiable reasons in the extraordinary unity and logic of its basic tenets. It verily solves with one stroke all the puzzles that had been set by the motion of bodies since Newton's time [...] in describing natural processes. ${ }^{37}$

The following list comprises FreUndLICH's various attempts to arrive at an experimental test of EINSTEIN's general theory of relativity.

Table 1. Summary of FREUNDLICH's attempts to verify relativity theory

End of 1911-Oct. 1912: Examination of available plate data from solar eclipse expeditions for evidence of light deflection in the sun's gravitational field; plates not sharp enough.

1912-1913: Comments on possible daytime observations of stars near the sun; but too much scattered light.

1913: Analyses of binary stars: Test of the axiom $c=$ constant of the special theory of relativity versus RITZ's emission theory of light.

1914: Analysis of FraUNHOFER-line measurements by EVERSHED (1913) and FABRY \& BUISSON [1910] with the view toward possible gravitational redshift; Results: redshift is present. But already in 1914 SCHWARZSCHILD publishes new data that rather speak against gravitational redshift.

1914: Expedition to the Crimea exclusively to verify light deflection during a solar eclipse; due to the outbreak of war, the members of the expeditions are taken into custody and their instruments confiscated.

37 "Die experimentelle Begründung der Einsteinschen Gravitationstheorie ist also noch nicht weit gediehen. Wenn die Theorie aber trotzdem schon heute den Anspruch auf allgemeine Beachtung erheben kann, so hat dies in der ungewöhnlichen Einheit und Folgerichtigkeit ihrer Grundlagen seinen berechtigten Grund. Sie löst in Wahrheit mit einem Schlage alle Rätsel, welche die Bewegung der Körper seit Newtons Zeit [...] für die Beschreibung der Naturvorgänge aufgegeben hatte." FreundLICH [1916]a pp. 391f. 
Table 1. (Contd.)

Feb. 1915: Refutation of V. SEELIGER's zodiacal light hypothesis as an explanation of anomalies in the planetary system; in Nov. 1915 EINSTEIN will explain the mercurial perihelion anomaly with his new theory.

1915ff.: Statistical investigations of redshift of fixed stars in relation to their spectral classification; observed redshifts are correlated with estimated mean masses and radii of the fixed stars. Results: redshift is present. But v. SEELIGer and LudendorfF accuse FREUNDLICH in the same year of technical errors and 'wishful thinking' [see the next section]. Repetition of these investigations: 1919, 1922, 1924, 1928, 1930.

1920-24: Building of the Einstein Tower, initially with the special aim of testing beyond any doubt the existence of redshift of the sun's spectral lines; while still in the construction stage, scope of analysis broadened - redshift never actually is confirmed beyond doubt at the EINSTEIN Tower.

1922: Solar eclipse expedition to Christmas Island, re light deflection.

1923: Solar eclipse expedition to Mexico, to test also for light deflection.

1926: Solar eclipse expedition to Bengkulen, South Sumatra, also re light deflection.

1929: Solar eclipse expedition to Takingeun, North Sumatra, to test also for light deflection; different from the preceding expeditions, for the first time good weather and successful procurement of observation data; the evaluation yields too large an effect of light deflection ( $2^{\prime \prime} .2$ instead of $1^{\prime \prime} .75$ at the sun's rim). (See Section 5).

1931ff.: Reanalysis of older data from other solar eclipse expeditions of 1922 and 1924 confirms the tendency: Light deflection is larger than predicted in the general theory of relativity.

1931-1965: Development of a phenomenological theory to explain the discrepancies between observations and the general relativity theory (photon-photon interaction) (See Section 6).

\section{Freundlich's Researches of 1915-16 on the Statistics of Fixed Stars: Statistical Evidence of Gravitational Redshift?}

This section covers in finer detail one of FREUnDLICH's efforts to carry out a re-evaluation of older data from the fresh point of view of whether as yet unrecognized relativistic effects might not possibly be concealed within it. As the foregoing summary has shown, FrEUNDLICH used this strategy on many occasions since 1911, and with completely different sets of data. On the one hand, he used older photographic plates which had been produced during solar eclipses, and on the other hand, he used measurements of spectral lines of the sun which had originally been made to determine the convection currents of the sun. FreundLICH's idea must be seen in light of the fact that his professional colleagues considered a verification of the relativistic effect of redshift in the solar spectrum to be very improbable, due to the interference of other inextricably overlapping effects. The general consensus appeared to be that "a final decision on this question [is] only possible on the basis of specific experiments 
throughout many years". ${ }^{38}$ In this situation, to verify the predictions of the general theory of relativity, it was necessary to perform skillful experiments (which Freundurch was not free to do at this time because he lacked suitable instruments) to "look for additional important points of attack in this important issue". ${ }^{39}$ The presence of a large gradient of gravitational potential, and thus a light source of great mass, was a precondition for obtaining experimentally verifiable gravitational redshift. Aside from the sun, fixed stars were therefore especially good candidates, as they were, if not comparable in size to the sun, often many times larger. But different from the sun, little was known a priori about their motion relative to the earth, so that the problem here immediately arose of distinguishing between the redshift resulting from gravitation and that resulting from the Doppler effect. The relative motions of the fixed stars away from the earth can be determined only by spectroscopy, i.e., by the Doppler redshift - now, a part of this observed redshift was supposed to be due to an unknown proportion of gravitational redshift. How could both proportions be clearly and indisputably separated from one another? As soon as Freunduich learned of the relativistic effect, he worked out a statistical procedure that he thought should be capable of doing this. He tabulated the known spectral-line shifts of all the visible fixed stars, uniformly distributed spatially and corrected for the solar apex. Assuming an isotropic universe, a distribution of stellar velocities should result which is "symmetrically grouped according to positive and negative velocities around the total zero". ${ }^{40}$ Yet his results were otherwise:

The velocities of the stars derived from the measured line shifts rather cluster around a positive value away from zero, this means, decidedly more positive velocities result than negative ones and specifically, particularly pronouncedly for the smaller velocities between -15 and $+15 \mathrm{~km}$ [per second] and for stars of a primeval spectral nature. $^{41}$

This result from an initial rough examination of the data becomes very apparent in the following table in which FreUNDLICH assembled separate observations by CAMPBELL and others in "condensed form" ("verkürzter Anordnung"):

38 "eine endgültige Entscheidung dieser Frage erst aufgrund langjähriger Spezialuntersuchungen möglich sein" wird. FREUNDLICH [1915/16]a p. 115.

39 nach "weiteren wichtigen Angriffspunkten für diese wichtige Frage suchen". FREUNDLICH $[1915 / 16] \mathrm{b}$ col. 17.

40 "symmetrisch nach positiven und negativen Geschwindigkeiten um den Betrag Null gruppiert". Ibid.

41 "Vielmehr häufen sich die aus den gemessenen Linienverschiebungen abgeleiteten Geschwindigkeiten für die Sterne gegen einen von Null abweichenden positiven Wert, d.h. es ergeben sich ausgesprochen mehr positive Geschwindigkeiten als negative und zwar besonders ausgesprochen für die kleineren Geschwindigkeiten zwischen - 15 und $+15 \mathrm{~km}$ [pro Sekunde] und für Sterne frühen Spektralcharakters." FrEUndLICH [1915/16]b col. 18. For later data, cf., e.g., TRÜMPLeR \& WeAver [1953], pp. 291, 354, 566. 
Table 2. Asymmetry of observed spectral line shifts of fixed stars, differentiated according to Doppler equivalence velocities for two separate types of spectral classifications; \# stands for number of stars. (FREUNDLICH $[1915 / 16] \mathrm{b}$ col. 19)

\begin{tabular}{lccc}
\hline Observed $v$ & \# (Type $\left.B-F_{4}\right)$ & \# $\left(F_{5}-M\right)$ & Total \\
\hline$>+30 \mathrm{~km} / \mathrm{s}$ & 6 & 57 & 63 \\
+15 to $30 \mathrm{~km} / \mathrm{s}$ & 39 & 104 & 143 \\
+0 to $+15 \mathrm{~km} / \mathrm{s}$ & 170 & 210 & 380 \\
-0 to $-15 \mathrm{~km} / \mathrm{s}$ & 86 & 207 & 293 \\
-15 to $-30 \mathrm{~km} / \mathrm{s}$ & 27 & 89 & 116 \\
$<-30 \mathrm{~km} / \mathrm{s}$ & 9 & 56 & 65 \\
\hline
\end{tabular}

If the observed line shifts are interpreted as Doppler shifts, then significantly more fixed stars show a movement away from the earth than towards the earth. Based upon a static cosmos, which was at that time generally assumed, ${ }^{42}$ this was highly implausible. That is why FREUNDLICH interpreted this result in such a way that an asymmetrically shifted gravitational redshift, which corresponds to a stellar system expanding on the order of $4-5 \mathrm{~km} / \mathrm{s}$, is superimposed upon a Doppler shift accidentally symmetrically arranged around the value zero. ${ }^{43}$ To clarify the question of whether the result was due to a systematic error, ${ }^{44}$ FREUNDLICH then discussed the line shifts separately for different spectral types according to CAMPBELL's classification $[1911]^{45}$

In order for Freundici to relate these redshifts to the predictions of the general relativity theory, he had to also determine the average mass of the fixed stars of these spectral classifications. Based upon the spectroscopic analyses by CAMPBELL and others of type B binary stars, FREUNDLICH set $\left(m_{1}+m_{2}\right)=14 m_{\odot}$ [Solar mass $\left.=\left(m_{\odot}\right)\right]$. Following the additional premise that "in all probability the percentage of spectroscopic binary stars among the class B stars [is] so large that it is justified to extend the data taken for our purposes from the

42 Even by EINSTEIN in his first cosmological application of his field equations of Feb. 1917, until the dynamic solutions of the field equations of FRIEDMAN, LEMAITRE among others in the 30 's - see, for example, the contributions of ELLIS and KERSZBERG in HOWARD \& STACHEL (Eds.) [1989], NORTH [1965], and references therein.

43 Gravitational redshifts can naturally also be given in units of Doppler shifts - then the relative motion is indicated which is necessary to yield the observed redshift ("Doppler equivalence velocities").

${ }^{44}$ These could originate, for example, from disregarding the differences of physical parameters of terrestial light sources (i.e., pressure, temperature, or field influences) as compared against the stars' atmospheres.

${ }^{45}$ FREUNDLICH then addressed in more detail only the spectral classes A and B, in his words "because the available observational data is not yet complete enough" ("weil das vorhandene Beobachtungsmaterial noch nicht vollständig genug ist"). See also LUDENDORFF [1916]. 
Table 3. Mean spectral line shifts for fixed stars in Doppler equivalence velocities $v$, differentiated according to spectral classification; \# again means number of stars (from CAMPBELL [1911]; reprinted, for example, in FREUNDLICH $[1915 / 16] \mathrm{b}$ col. 19)

\begin{tabular}{lcc}
\hline Type & \# (Stars) & $v(\mathrm{~km} / \mathrm{s})$ \\
\hline B-Bs & 177 & 4.7 \\
A & 177 & 1.0 \\
F & 185 & 0.1 \\
G & 251 & 0.0 \\
K & 751 & 2.6 \\
M & 143 & 4.3 \\
\hline
\end{tabular}

binary stars to all known class B stars", ${ }^{46}$ this was also possible. If the observed average redshift for class B stars (defined by strong He-lines) were entirely an effect of gravitation, then of course the mean gravitation potential, or its mass, could be extrapolated. FREUNDLICH arrived at $20 m_{\odot}$, which correspond at least in order of magnitude to the estimate of the mean mass of class B stars stemming from binary systems. Using the same procedure, he calculated estimates of the average masses for class A stars from binary systems as well as by gravitational redshift, ending up with 4 to 5 times the size of $m_{\odot}$ for both estimates, which thus happily lead to the same orders of magnitude. He saw in this coherence of order of magnitude estimates an indication of the actual existence of gravitational redshift.

EINSTEIN welcomed this result and rated FREUNDLICH's work in a letter to SOMMERFELd as "surely fundamental". ${ }^{47}$ The most vulnerable spot in FreUNDLICH's arguments (disregarding the ambitious extrapolation of binary star systems to all stars of one class and the incomplete observational data) was hidden within a formula which determined the relativistic correlation of the observed line shift $f$ with density $\rho$ and mass $m$ in units of solar mass $m_{\odot}$, or solar density $\rho_{\odot}$. In his first short notice, FreundLICH had set $m=f / \sqrt{\rho}$ and

46 "aller Wahrscheinlichkeit nach der Prozentsatz spektroskopischer Doppelsterne unter den B-Sternen ein so großer [ist], daß man berechtigt ist, die für unseren Zweck aus den Doppelsternen abgeleiteten Daten auf die Gesamtheit aller bekannten B-Sterne auszudehnen". FREUNDLICH [1915/16]b col 21.

47 "sicher fundamental". EINSTEIN to SOMMERFELD, 15 July 1915, published in HERMANN (Ed.) [1968], p. 30. 
after inserting the observed shift $f^{0}$ and the estimated density $\rho=1 / 10 \rho_{\odot}$, he determined from this: ${ }^{48}$

$$
m=f^{0} \cdot \frac{1}{\sqrt{\rho}} \simeq 15 m_{\odot} .
$$

The astronomer Ritter Hugo von SEELIGER ${ }^{49}(1849-1924)$ noticed the deficiency in this formula. Relative line shift $f=f^{0} / f_{\odot} \simeq 4.5 / 0.6$ and gravitational potential $\phi$, radius $r$, density $\rho$ and mass $m$ according to general relativity theory are connected in the following manner:

$$
\begin{aligned}
f=\phi / c^{2} \sim \phi=m / r ; \rho \sim m / r^{3} & \Rightarrow f=(m \cdot \sqrt{\rho})^{2 / 3} \\
& \Rightarrow m=f^{3 / 2} \cdot \frac{1}{\sqrt{\rho}} \simeq 65 m_{\odot} .
\end{aligned}
$$

He passed this correct formula on to FrEUndLICH's superior, HERRMANN Struve, ${ }^{50}$ who in turn informed Freundlich. That v. SeEliger should choose this indirect path through STRUVE, which for members of one and the same professional community was actually quite unusual, instead of informing FREUNDLICH personally, is explained by the fact that the two had already come into conflict on another occasion. FREUNDLICH had just published a critical paper in 1915 on v. SEELIGER's zodiacal hypothesis, in which he showed that the latter's hypothesis was unable to explain observed anomalies, particularly of Mercury and Venus in the planetary system. ${ }^{51}$ In this respect the discovery of this hasty error in FREUNDLICH's paper was a welcome opportunity to v. SEELIGER to strike back. On 7 August 1915 FreUndLICH wrote to Struve that he was "very disheartened" that "such a gross and unnecessary mistake could still happen" to him, that he thanked v. SEELIGER for the information and would make a correction. ${ }^{52}$ This correction appeared in the Astronomische Nachrichten [1916], albeit without naming V. SEELIGER, with the following comment:

At this point $I$ would not like to forget to add that in the previous communication on this question [...] an error had slipped in, where a formula appears which I had initially only used for rough calculations $[\ldots] .^{53}$

48 See FreUndLICH $[1915 / 16]$ a p. 117 ; if the relative shift $f=f^{0} / f_{\odot}$ is inserted as it should be, the result is $23.7 m_{\odot}$ !

49 From 1882 professor of astronomy and director of the observatory at Munich University as well as from 1897 to 1921 president of the Astronomische Gesellschaft. On v. SeEliger, see Eddington [1925], Kienle [1925].

50 On 27 June 1915; see (AAW), Babelsberg Observatory, folder 65, sheets 16-17. [1974].

51 See in this regard Freundlich [1915]; see also v. SeEliger [1915], Pyenson

${ }^{52}$ Freundlich to Struve, 7 Aug. 1915: Er sei "sehr niedergeschlagen", daß ihm "ein so grobes und unnötiges Versehen noch passieren kann", see (AAW), Babelsberg Observatory, folder 65, sheet 19. 
FREUNDLICH also mentions there that with the change in the formula, the consistency between relativity theory and observation had been damaged, at least if the old estimated values for the density of class B stars were adopted.

If one were to introduce into this formula 0.1 solar densities as the average density of class B stars, as is concluded from an analysis by H. Shapley (A[stro]P[hysical].J[ournal]. 38. 158), then the result is not a favorable one. Our knowledge of the density of the stars is not yet remotely sufficient to require that this value apply to all class B stars. ${ }^{54}$

With a somewhat vague reference to analyses by HeNry NorRis Russell "and others" on the mean mass dependent upon spectral type, according to which class B stars take on a "middle position", Freundulch then based the new estimate of the density, so critical in the formula for the observed shift as a function of mass, as 0.5 solar densities. With this, "approximately $25-30$ solar masses" was then again still acceptably consistent with the value $15 m_{\odot}$ proposed by the theory. ${ }^{55}$

Three issues later, as could almost be expected, Freundich's opponent Hugo v. Seeliger censured not only FreundLici's new version, in which his correction had been incorporated without any acknowledgment, but also the whole line of reasoning as well. FreUnDLICH's paper was now in a manner of speaking publicly torn to bits. On the basis of the correct formula (2) for the shift as a function of density $\rho$ and mass $m:\left[m=f^{3 / 2} \cdot(1 / \sqrt{\rho})\right]$ with FreUndLich's original figures $f=4.5 / 0.6$ and $\rho=1 / 10 \rho_{\odot}$ the mass of class $\mathrm{B}$ stars comes to 65 solar masses, and by no means to the value indicated, supported by relativity theory of 14 solar masses: "and the desired conformity has turned into a total failure". ${ }^{56}$

After this remark, v. Seeliger then continued to show how Freunduich had altered the density $\rho$ in order to maintain a value compatible with the mass from the binary star estimate for class B stars, instead of taking $\rho=1 / 10 \rho_{\odot}$ (as initially) in his "improved paper", he had applied $\rho=0.5 \rho_{\odot}$, in order to arrive

53 "Ich möchte an dieser Stelle nicht vergessen einzuschalten, daß in der vorläufigen Mitteilung über diese Frage $[\ldots]$ ein Fehler unterlaufen ist, indem dort eine Formel abgedruckt ist, die ich zu Anfang nur zu Überschlagsrechnungen verwandt hatte [... ]." FREUNDLICH [1915/16]b col. 21.

54 "Führt man in diese Formel als mittlere Dichte der B-Sterne 0.1 Sonnendichten ein, wie sie aus einer Untersuchung von H. Shapley (AP. J. 38. 158) herauskommt, so ist das Resultat kein günstiges. Unsere Kenntnis über die Dichten der Sterne reichen aber noch nicht entfernt aus, diesen Wert für alle B-Sterne zu fordern." FrEUNDLICH [1915/16]b col. 21-22.

55 "mittlere Stellung"; "ungefähr 25-30 Sonnenmassen". All quotes again from FREUNDLICH [1915/16]b col. 22.

56 "und die gewünschte Übereinstimmung hat sich in einen vollständigen Mißerfolg verwandelt". VON SEELIGER [1916] col 84. 
at $25-30 m_{\odot}$ (by the way, "towards the more favorable side of the averaged values"). ${ }^{57}$ As v. SEeliger explained further, in order to arrive at the binary star estimate for class B stars determined by CAMPBELL at $14 m_{\odot}$, a hypothetical density of 2.2 would have to be assumed, which appeared to him to be simply unacceptable. ${ }^{58}$ For v. SEeliger all these arbitrary adjustments of only indirectly determinable parameters showed "how arbitrary and meaningless the whole calculation is". ${ }^{59} \mathrm{He}$ concluded as follows:

The result of the whole study is thus, that as long as Ludendorf's and Campbell's figures are retained, not only can an indication of the presence of a gravitation effect not be proved, but on the contrary, the latter can only be completely contradicted. Criticizing the data used is as little the intent of these lines as it is criticizing Einstein's theory. The object is only to present Mr. Freundlich's method of observation and the manner in which he evaluates clarifications which are brought to his attention. ${ }^{60}$

As sloppily as FreundeIch may have argued in his papers, it is nevertheless astonishing with what energy the otherwise rather principled pen of v. SEELIGER 'slashed away' at FreundLICH. The full extent of his irritation in this matter only becomes clear in a private letter which v. SEELIGER had written at this time to STRUVE directly after he had read FreUnDLICH's 'improved paper', the controversial parts of which, in v. SeELIGer's opinion, are

scientifically disingenuous - to put it mildly - the likes of which has never happened before in my 40 years of experience in science. Scientific decency, which is otherwise practised without exception, would have required that the source of the correction be indicated, and scientific honesty should have prevented such distortions of the real state of the facts. The other salvaging attempts with the obvious tendency to cover up have completely miscarried as well. [...]. But in the interest of our science I cannot silently accept Mr. F's entire outrageous proceedings, and I will bring it out before the public in some form or other, even though I keenly regret charging one of your official employees with such a serious reproach. ${ }^{61}$

57 "nach der für ihn günstigeren Seite abgerundete Werte". Ibid.

58 "nicht annehmbar". Ibid. VON SEELIGER naturally could not know that developments in the decades subsequent to this debate led to the permissibility of much higher stellar densities.

59 "wie willkürlich und nichtssagend die ganze Rechnung ist". VON SEELIGER [1916] col. 85 .

60 "Das Resultat der ganzen Betrachtung ist also, daß, so lange man die Ludendorffschen und Campbellschen Zahlen beibehält, nicht nur keine Andeutung für das Vorhandensein einer Gravitationswirkung nachzuweisen ist, vielmehr nur ein vollkommener Widerspruch gegen die letztere. Eine Kritik der angenommenen Daten liegt diesen Zeilen ebenso fern wie eine solche an der Einsteinschen Theorie. Es sollte nur die Betrachtungsmethode des Herrn Freundlich und die Art, wie er ihm übermittelte Aufklärungen verwertet, geschildert werden." Ibid., col. 86.

${ }^{61}$ stellen "eine wissenschaftliche Unaufrichtigkeit - um ein mildes Wort zu gebrauchen - dar, wie sie mir in gleichem Grade während meines 40-jährigen wissenschaftlichen Tätigkeit noch nicht vorgekommen ist. Der wissenschaftliche Anstand, der sonst 
The outburst of anger in this letter becomes comprehensible with the knowledge that v. Seeliger was known as an opponent to relativity theory. In this regard it was immediately clear to all readers of this notice, despite the explicit statement to the contrary, that v. Seeliger thought to also be able to land a stinging blow on the 'relativistic fad'. This is directly supported in another of v. SeELiger's letters to Struve, in which he gives he reasons why he bothers to write responses to Freunduich:

That was, by the way, only urgent to the extent that I happened to hear that Einstein sets great store in Dr. F's line of reasoning. You know that I am extremely sceptical of many hypotheses of the latest physics, and that is why the question under discussion seemed to me to be of some interest. ${ }^{62}$

This means that v. SEELIGER (and others after him) attacked FreundLICH, but meant EINSTEIN. The latter knew perfectly well who was being targeted: EINSTEIN wrote to his Munich colleague SOMMERFELD in his characteristically humorous tone: "Tell your colleague [von] Seeliger that he has a ghastly temperament. I relished it recently in a response he directed to the astronomer Freundlich" ${ }^{63}$ Through his reckless advocacy of the theory of relativity, therefore of EINSTEIN's business, Freundlich became from 1915 on the whipping boy for the to a large part conservative and anti-relativistic community of astronomers in Germany. It thus becomes clear here, that the story, which up to now had been set as a drama between several actors (Freundlich, Einstein, Struve and v. Seeliger), that is, still concerning individuals, now is complicated by cognitive and social components, as here the preponderantly critical reception of relativity theory within the scientific community prior to 1919 . This episode was to have repercussions for Freunduich also in his later professional life (see p. 184).

ausnahmslos geübt wird, hätte erfordert, die Quelle anzugeben, von wo die Richtigstellung erfolgt ist, und die wissenschaftliche Aufrichtigkeit hätte vor solchen Verdrehungen des wahren Sachverhaltes abhalten sollen. Auch die weiteren Rettungsversuche mit der offenbaren Tendenz zu verschleiern sind durchaus verfehlt. [...]. Das ganz unerhörte Verfahren des Herrn F. kann ich aber im Interesse unserer Wissenschaft nicht stillschweigend hinnehmen u. ich werde es in irgend einer Form vor die Öffentlichkeit bringen, obwohl ich es lebhaft bedaure, einen Ihrer Beamten mit so schwerem Vorwurf zu belasten." VON SEeliger to Struve, 12 Jan. 1916, (AAW), Babelsberg Observatory, folder 65, sheets 41-42; reprinted in KIRSTEN \& TREDER (Eds.) [1979] pp. 181 .

62 "Die Sache war übrigens nur insofern dringend, als ich zufällig hörte, daß Einstein auf die Beweisführung des Herrn Dr. F. großen Wert legt. Sie wissen, daß ich vielen Hypothesen der neuesten Physik äusserst skeptisch gegenüberstehe und deshalb schien mir die besprochene Frage einiges Interesse zu haben." Von SeEliger to Struve, 15 Aug. 1915, (AAW), Babelsberg Observatory, folder 65, sheet 15.

63 "Sagen Sie Ihrem Kollegen [von] Seeliger, dass er ein schauerliches Temperament hat. Ich genoss es neulich in einer Erwiderung, die er an den Astronomen Freundlich richtete". A. EINSTEIN to SOMMERfeld, 9 Dec. 1915, in Hermann (Ed.) [1968] p. 37. 
In view of the correlation between theory and experiment, this case study shows how much Freundurch had been guided in his study of old observational data by his desire to verify gravitational redshift-parameters which had not yet been definitively determined, as here the mean density of class B stars, were chosen at will so as to attain an approximate consistency with the anticipations of the general theory of relativity. Such a 'fine tuning' of the variables, a thoroughly common procedure in particle physics for adapting hypothetical models of processes to observation, taken by itself, in the long run does not produce credible results. ${ }^{64}$ In order to convince others, FrEUNDLICH would have to justify why he chose to set the relative density at 0.1 and then suddenly a year later at 0.5 . But this is too much to ask of him in view of the still very inadequate observational data. The result of FrEUNDLICH's studies quickly concluded by the field was thus, that the effect could among others be involved, but not that it necessarily is involved. Interestingly enough, FreunduICH repeated this methodological error of not being critical enough with regard to his own interpretation of his data several times in his later researches.

Yet, EINSTEIN attempted to extract a somewhat more positive finding out of Freundich's studies on the statistics of fixed stars. In his discussion of the foundations of the general theory of relativity of 1916 he added the following cleverly worded comment, in which he denied any personal responsibility, dropping the results in FREUNDLICH's lap:

The existence of such an effect [of gravitational redshift] is supported, according to E. Freundlich, by spectral observations of certain types of fixed stars. A final verification of this consequence has yet to be made..$^{65}$

In light of the previously described controversies about FreunduICH's liberal adaptation of variables, this statement sounds highly euphemistic. When in February of 1916 STRUVE furnished him with the issue of the Astronomische Nachrichten containing v. SeEliger's reply to FreundLich and a survey by LUDENDORFF of the current knowledge on the 'Masses of Spectroscopic Binary Stars', EINSTEIN responded, obviously unimpressed by v. SEELIGER's shattering results, and no less convinced of the validity in principle of the path shown by FREUNDLICH:

64 This also applies to today's high-energy physics, the individual theoretical departments of which have the task of finding the reasons why certain parameters (such as, for example, bonding strengths at specific energies) have exactly one and not another value - only by connecting phenomenological models to larger theoretical networks do they then become credible.

65 "Für das Bestehen eines derartigen Effektes [der Gravitations-Rotverschiebung] sprechen nach E. Freundlich spektrale Beobachtungen an Fixsternen bestimmter Typen. Eine endgültige Prüfung dieser Konsequenz steht indes noch aus." EINSTEIN [1916]b p. 123. 
Thank you very much for the issue of the Astronomische Nachrichten [. . . . Seliger's [sic] article tells me nothing new. Ludendorff's I found very interesting, from which I learn how incomplete the observational data up to now still is. But the good news is that one gets the impression that data which will permit a definite decision will come in bit by bit.

Attached to Ludendorff's article is the question:

Do weaker stars of the same spectral class in general also have a smaller mass? This could be answered in the case of binary stars, the mass size of which can be obtained through averaging. If there should turn out to be a significant correlation, then Ludendorff's approach could prove to be very valuable in the future. As long as the average error exceeds the determined redshift [...], the result remains completely uncertain $[\ldots]$.

In any case, I see that Freundlich's result is by no means secure (not even qualitatively). $\left[{ }^{66}\right]$ However, credit should be given to Freundlich for having been the first to have brought attention to a practicable way of testing the question. ${ }^{67}$

Even though EINSTEIN was not fully convinced by v. SEeliger and LudENDORFF's objections, it did become clear to him on the occasion of this ugly controversy between Freundich and his opponents, how much Freundulch had already been pushed to one side as a result of his overeager attempts to find a verification of the general theory of relativity. Even EINSTEIN's advocates, such as, for example, Arnold Sommerfeld in Munich took v. Seeliger's side in his quarrel with Freundlich and advised EINSTEIN to distance himself from Freunduich. EINSTEIN followed this advice: he increasingly disassociated himself personally from his intellectual disciple, without actually breaking all ties, however, since he still needed FreunduICH.

66 The parenthetical comment was added by hand by EINSTEIN.

67 "Ich danke Ihnen bestens für die Nummer der Astronomischen Nachrichten [...]. Der Seliger'sche [sic] Artikel zeigte mir nichts Neues. Sehr interessant war mir der Ludendorff'sche, aus dem ich ersehe, wie unvollkommen das bisherige Beobachtungsmaterial noch ist. Das Erfreuliche aber ist, dass man den Eindruck gewinnt, dass sich nach und nach Material wird gewinnen lassen, welches eine sichere Entscheidung zulassen wird.

An den Artikel von Ludendorff lässt sich die Frage knüpfen:

Sind schwächere Sterne desselben Spektraltypus durchschnittlich auch von kleinerer Masse? Dies wäre bei Doppelsterenen beantwortbar, bei denen man die Grösse der Masse mitteln kann. Ergäbe sich eine bedeutende Abhängigkeit, so könnte die Ludendorff'sche Betrachtungsweise in der Zukunft [sich] als sehr wertvoll erweisen. Solange der mittlere Fehler die ermittelte Rotverschiebung übersteigt [...], ist das Resultat ganz unsicher $[\ldots]$.

Jedenfalls sehe ich, dass Freundlichs Ergebnis keineswegs gesichert ist (nicht einmal qualitativ). Dagegen muss man. Freundlich zugute halten, dass er zuerst auf einen gangbaren Weg zur Prüfung der Frage aufmerksam gemacht hat." EINSTEIN to STRUVE, 13 Feb. 1916, (CPAE), call no. 22 299, or (AAW), Babelsberg Observatory, folder 65, sheet 54, reprinted in KIRSTEN \& TREDER (Eds.) [1979] Vol. 1, p. 173; original spelling. 
Seen from my point of view, the affair looks like this. Freundl[ich]. was the only colleague in the field [of astronomy] to have effectively supported my efforts up to now in the area of general relativity. He devoted years of thought, and of work as well, to this problem, inasmuch as this was possible next to the strenuous and tedious duties at the observatory. [.. ]. I simply lack contacts in astronomy ${ }^{68}$

In EINSTERN's letters to third parties we find, aside from carefully formulated acknowledgments of FrEUNDLICH's efforts, also astonishingly deprecating comments about his qualities as a scientist and as a person. ${ }^{69}$ After FreUndLICH had made such a flop of an attempt to find statistical proof of gravitational redshift in the spectra of fixed stars, EnNSTEIN apparently saw the danger that his own reputation and that of the theory, which both he and FREUNDLICH were advocating, might suffer as a result. When he distanced himself from FreUndLICH in his communications with Struve, he thus prevented any of Freundlich's blunders from falling back directly into himself as well. ${ }^{70}$ How realistic EINSTErN's suspicion was, is shown in the following excerpt from a letter by Sommerfeld to Hermann Weyl, indicating that Sommerfeld at this time considered the likelihood of experimentally verifying gravitational redshift to be very poor, despite FreundLICH's efforts, and that SOMMERFELD already considered him to have fallen into disrepute:

But above all I would like to refer you [...] to the redshift of spectral lines. Up to now no indication of this has appeared. Schwarzschild did not find any; new careful American measurements at Mt. Wilson also did not. I would be interested to find out from you when there is a chance, whether redshift is unavoidable in your theory as well. What Freundlich has published on this, as a purported verification of the same, is more or less a fraud. ${ }^{71}$

68 "Von meinem Standpunkt aus betrachtet sieht die Angelegenheit so aus. Freundl[ich]. war der einzige Fachgenosse, der mich bis jetzt in meinen Bestrebungen auf dem Gebiete der allgemeinen Relativität wirksam unterstützte. Er hat dem Problem Jahre des Nachdenkens und auch der Arbeit gewidmet, soweit dies neben dem anstrengenden und stumpfsinnigen Dienst an der Sternwarte möglich war. [.. ]. Mir fehlt eben der Kontakt zur Astronomie." EINSTEIN to ARNOLd SOMMERFELD, 2 Feb. 1916, only partially published in HERMANN (Ed.) [1968], pp. 38-39; see also PYENSON [1974] pp. $330-332$.

${ }^{69}$ Such as, for example, in January 1916 to SCHWARZSCHILD, in February 1916 to SOMMERFELD (see above), and in the last paragraph of the previously cited letter to STRUVE (cited in HentSCHel [1992]b p. 48.

70 EINSTEIN again followed this same strategy later with regard to HANS LUDENDORFF, FREUNDLICH's most influential opponent from $1920-$ re LUDENDORFF, see HENTSCHEL [1992]b pp. 128ff.

71 "Vor allem aber möchte ich Sie [.. ] auf die Rotverschiebung der Spektrallinien hinweisen. Bisher hat sich keine Andeutung davon gezeigt. Schwarzschild hat sie nicht gefunden, neue sorgsamste amerikanische Messungen auf dem Mt. Wilson ebenfalls nicht. Es würde mich interessieren, gelegentlich von Ihnen zu erfahren, ob die Rotverschiebung auch in Ihrer Theorie unvermeidlich ist. Was Freundlich darüber publiciert hat, als angebliche Bestätigung derselben, ist mehr oder minder Schwindel." SOMMERFELD to 
When an influential supporter of relativity theory speaks of 'fraud' with reference to FREUNDLICH's experiments, then the situation is serious indeed. In 1919 the tone of EINSTEIN's letters to others (including sympathizers) when speaking about FreUnduich had significantly changed, however. ${ }^{72}$ EINSTEIN wrote to EDDington on 15 Dec. 1919 among other things that he was very pleased that EDDINGTON had offered a few words of acknowledgment to FreundLICH. "He is very diligent, but as a result of material and personal impediments has not been able to contribute much yet to the theory". ${ }^{73}$ Nevertheless EINSTEIN supported his protégé in the particularly economically unfavorable situation of post-war Germany, first of all by engaging him as the first full-time employee of the Kaiser-Wilhelm-Institut für physikalische Forschung from the end of 1917, then by signing a funding petition which formed the basis of the 'Einstein-Spende' or Einstein donation, with which the Einstein Tower was then financed. ${ }^{74}$

After a big row about one of EINSTEIN's manuscripts in 1921, FreunduICH's relationship with EINSTEIN cooled significantly. According to FreUndurch's account, he had with EINSTEIN's consent wished to sell an EINSTEIN manuscript to help finance research at the Einstein Tower, while EINSTEIN suddenly insisted that he had only lent the manuscript and demanded that it be returned. ${ }^{75}$ Attempts at mediation between the two, such as those by ARnold BerLiner, the editor of the journal Die Naturwissenschaften, in which both EINSTEIN and FreUndLICH published from time to time, remained unsuccessful; ${ }^{76}$ EINSTEIN wrote the following to the self-assigned arbitrator, who called LUDENDORFF's furious outburst against FreUnDLICH at a trustees' meeting "inappropriate" and "insulting" and who condemned the form of these attacks against Freundurch:

On the one hand I am pleased that you have such a strong moralistic streak. On the other hand I am sorry that you waste your feelings on such unworthy objects. At any rate I must say that though L[udendorff]. appears to be considerably the clumsier of the two, he nonetheless appears to be much the more decent. I for my part do not consider it beneficial for me to interfere in any way in this argument, but will respectfully deposit your letter in what corresponds here to what you would call the files. ${ }^{77}$

WEYL, 7 July 1918, (ETH), call no. HS 91: 751, my emphasis. My attention was brought to this letter through SigurdsSON [1991] p. 160.

72 See, for example, EINSTEIN [1917]b p. 90.

73 "Er ist sehr eifrig, hat aber infolge sachlicher und persönlicher Hindernisse noch nicht viel zur Prüfung der Theorie beitragen können". (CPAE), call no. 9263.

74 See on this HENTSCHEL [1992]b chapter 8.

75 See the FREUNDLICH-EINSTEIN correspondence, (CPAE), call nos. 11 318-11 321, as well as FreUNDLICH to REICHENBACH, 2 Mar. 1922, (ASP), call no. HR-15-53-04.

76 See Berliner to EINSTEIN, 26 Jan. 1929, (CPAE), call no. 11301.

77 "Einerseits freue ich mich, dass Sie eine so kräftige moralische Ader haben. Anderseits tut es mir leid, dass Sie Ihre Gefühle an so wenig würdige Objekte verschwenden. Immerhin muss ich sagen, dass mir L[udendorff]. zwar als der wesentlich ungeschicktere, aber doch als der weitaus anständigere von Beiden erscheint. Ich meinerseits halte es nicht für erspriesslich, mich irgendwie in diese Streiterei einzumischen, nehme 
As things developed, EINSTEIN no longer participated other than strictly as an observer for the remainder part of his residence in Berlin: Important duties, such as directing the Kaiser-Wilhelm-Institut für Physik and presiding over board meetings such as those of the Einstein-Stiftung, were performed de facto by MAX vON LAUE and other people around him. ${ }^{78}$ How much EINSTEIN's relationship to FREUNDLICH had deteriorated in the 20's is illustrated in a letter he sent in 1925 during one of the many arguments between the two to Freundlich's archenemy LudendorfF, maybe in order to make him more willing to compromise, but maybe also simply out of annoyance.

With regard to Mr. Freundlich, you know my opinion, of course. In any case I have broken off personal relations with him and could have added a few very fine "specimens" to your reported list of sins. He counts among the very few, with whom I consider such a rigid attitude necessary. But I respect his organizational achievements and act accordingly, as you have also most commendably done on the occasion of his appointment. Thus we both serve the cause, even though we value the man and the scientist little. He is not worth getting upset about. ${ }^{79}$

A final remark on FREUNDLICH's investigations in fixed-star statistics, which he incidentally took up again in 1919,1922, 1924, 1928 and 1930: Contrary to EINSTEIN's and FREUNDLICH's optimistic expectations of verifying the general theory of relativity along this route, it turned out that the matter was very much more complicated than they could have known. Both had started at this time from the premise of a static cosmos, in which on the average no Doppler redshift should be expected from faraway objects relative to the earth; and in the first years of applying general relativity theory to cosmological problems, EINSTEIN categorically rejected the possibility of dynamic results of field

aber Ihren Brief respektvoll zu demjenigen, was bei mir dem entspricht, was Sie Akten nennen." Einstein to BERliner, 30 Jan. 1929, (CPAE), call no. 11302.

78 See on this, documentation in KIRSTEN \& TREDER (Eds.) [1979].

79 "Was Herrn Freundlich betrifft, so wissen Sie ja meine Meinung. Ich habe ja jedenfalls die persönlichen Beziehungen zu ihm abgebrochen und hätte dem von Ihnen verlesenen Sündenregister noch recht hübsche "Piecen" hinzufügen können. Er gehört zu den ganz wenigen, bei denen ich eine so schroffe Haltung für nötig erachte. Ich achte aber sein organisatorisches Verdienst und handle demgemäß, wie Sie es in anerkennenswertester Weise bei Gelegenheit seiner Ernennung auch getan haben. So dienen wir beide cer Sache, wenn wir auch den Menschen und Wissenschaftler gering einschätzen. Er ist es nicht wert, daß man sich über ihn ärgert." EINSTEIN to LUDENDORFF, 15 Sept. 1925, reprinted in KIRSTEN \& TREDER (Eds.) [1979] Vol. 1, p. 196; this letter has only survived in the form of LUDENDORFF's transcription, but an answering letter by LUDENDORFF preserved at (CPAE) makes the content plausible. This letter has exactly the same tone as the one written 10 years earlier to StRuVE (see above). For more on Freundulch's fate which lead him to emigrate after 1933, along with hundreds of other professors, first to Istanbul, then to Prague and from there to St. Andrews in Scotland, see HENTSCHEL [1992]b pp. 151ff. and HOFFMANN [1991]. 
equations shown by FrIEDMan. ${ }^{80}$ However, HubBLE's investigations showed in the twenties that the cosmos actually is expanding so that faraway fixed stars are moving, at a speed proportionate to their distance, away from the earth. ${ }^{81}$ Thus, the redshifts in the spectra of fixed stars were obscured by cosmological problems as well as by the effects of star development, and until more was understood about these factors, there was no hope of proving gravitational redshift through statistics of fixed stars.

What remains, however, is that FREUNDLICH's controversial research actually rather achieved the opposite of what he had so enthusiastically intended. Instead of inspiring confidence in the existence of an 'Einstein effect', there was rather an increased distrust towards new simplistic (monocausal) explanations. The dominant attitude among theorists and experimenters with regard to what lay ahead was pared down to scepticism about what could be drawn from existing and earlier experiments and hope for quantitatively more reliable experiments in the future in which disturbing side-effects could be eliminated. In addition to effects of pressure, there were, of course, temperature deviations within the spectroscope, the influence of electric and magnetic fields (STARK and ZEEMAN effects), as well as the influence of current parameters (pole effect), in the spark and arc spectra used for comparison purposes. All of these in the laboratory clearly established effects, along with other effects anticipated by the theorists (such as, for example, the possible influence of anomalous dispersion), had to be removed from 'corrected data' before gravitational redshift could become evident. ${ }^{82}$

\section{Freundlich's Solar Eclipse Expeditions: Photographic Evidence of Gravity's Influence on Rays of Light?}

The second area of emphasis of FrEUnDLICH's researches to experimentally test relativity theory lay in his studies of light deflection in a gravitational field, which he repeatedly returned to over many decades. After Freundulch had recognized in 1913 that going back to the existing photographic plates from earlier solar expeditions could not yield any adequately precise data on the positions of the stars forming the back-drop to solar photographs (see Section 3), he turned his attention to detecting light deflection at future solar eclipses. His correspondence with CAMPBELL shows, for example, that he urged the American observers as well as C. D. Perrine of the Cordoba Observatory to

${ }^{80}$ See on this, for example, the documentation in NORTH [1965] chapters $5 \mathrm{ff}$., HENTSCHEL [1990] section 1.4.

81 See on this, for example, North [1965] chapter 7, Hetherington [1982].

82 See in this regard, for example, Forbes [1963]. Hentschel [1992]a, b, [1993]a, b. 
include this test among their measurements scheduled to be performed during the next solar eclipse expedition on 21 August $1914 .^{83}$ Since CAmpbell could not definitely promise this to him in $1913,{ }^{84}$ FreundLich also attempted to organize in the last minute at the end of 1913 his own German expedition into the area of total solar eclipse in the Crimea. ${ }^{85}$ Through his position in the Prussian Academy of Sciences (Preussische Akademie der Wissenschaften), as well as in the Kaiser Wilhelm Institute for Physics (Kaiser-Wilhelm-Institut für physikalische Forschung) which had been established for him in 1917, EINSTEIN was well placed in the scientific scene in Berlin to help him hunt down sources of funds. As soon as he received the particulars from Freunduich, EInStein pulled the levers he could assume would lead to success. Through PlancK, who "really earnestly" advocated the matter and even undertook to discuss it with the astrophysicist Karl Schwarzschild ${ }^{86}$ (1873-1916), Einstein applied to the Prussian Academy for a grant for FreunduICH's planned expedition. But even their support was no conditio sine qua non, as he pointed out to Freundlich:

If the Academy is not keen on becoming involved, then we will get that little bit of mammon from private quarters. Right after the Academy has informed us of its negative decision, I will with Haber's help, touch Mr. Koppel $\left[{ }^{87}\right]$ who, as you know, had provided the money for my salary as academician. Should all else fail,

83 See, e.g., Freundlich to CAMPbell, 6 Feb. 1913, (AlO), Campbell Papers, folder FrEUNDLICH.

84 See Camprell to Freundlich, 6 Mar. 1913, (ALO): "If the Lick Observatory organizes an expedition to observe the total solar eclipse in Russia, August 1914, we shall plan to obtain photographs meeting the requirements of your problem; that is, with the solar image in the center of the field and with the driving clock adjusted to follow the stars. It is not certain that we shall send an expedition, but I hope that we may. [...]. However, as we say in this country, it is well not to count the chickens before they are hatched; that is, we may not go to the eclipse, or if we go, clouds or other features may prevent the success of our plans." CAMPBELL then actually did succeed in getting funding for the expedition (see his telegram to FREUNDLICH of 27 May 1913 and FrEUNDLICH's reply of 28 May 1913), but the expedition failed to bring home any usable exposures.

85 For details on the preparations for the expedition, see KIRSTEN \& TREDER (Eds.) [1979], Vol. 1, chapter IV, in particular, FREUNDLICH's application for funding: "Gesuch an die Akademie der Wissenschaften um Unterstützung für die Teilnahme an der Sonnenfinsternisexpedition auf die Krim", pp. 164-166.

86 From 1909 the director of the Astrophysikalisches Observatorium in Potsdam and member of the Preußische Akademie der Wissenschaften. On SCHWARZSCHILD, see, e.g., EINSTEIN [1916]a, SOMMERFELd [1916], HerTZSPRUNG [1917], BLUMENTHAL [1918], Oppenheim [1923], Ten BrugGencate [1955], Treder [1974], Diecke [1975].

${ }^{87}$ LEOPOLD KOPPEL (ca. 1854-1933) was a banker who had provided the Prussian Academy with an endowment called 'Stiftungsfond der mathematisch-physikalischen Klasse' - see KIRSTEN \& TREDER (Eds.) [1979] Vol. 1, pp. 102-103. 
then I will pay for the matter myself out of my little bit of savings, at least the first 2,000 M[arks]. So, after careful consideration, go ahead and order the plates and don't let the time $\left[{ }^{88}\right]$ slip by on account of money. ${ }^{89}$

In the end EINSTEIN did not have to pay the 2,000 marks out of his own pocket, since the Akademie der Wissenschaften approved the purchase of scientific instruments and photographic plates costing 2,000 marks, due to the support of its permanent secretary PlanCK, as well as that of NerNst. ${ }^{90}$ FreUnduICH received contributions of equal size also from private funders for his expedition. ${ }^{91}$ But the very fact that EINstern would have used his own savings if necessary in order to make sure that FREUNDLICH's expedition took place, shows how important FreUndurCH's project of 1914 was to him. ${ }^{92}$ When he learned about the approval of his grant application to the Academy in March 1914, EINSTEIN immediately wrote to FrEUNDLICH:

You can imagine how pleased I am that the external difficulties of your project are now overcome, so to speak. It is just as nice that all the persons involved have behaved themselves so well in this affair. Planck especially, I cannot praise enough. $[\ldots]^{93}$

However, Freunduch's solar eclipse expedition of 1914, in which apart from FreUndLICH, another employee at the observatory (Dr. W. ZuRhelLEN) and a mechanic from the manufacturer of fine optical equipment Zeiss-Werke (R. MECHAU) participated, failed because the First World War broke out, and FreUNDLICH together with his collaborators were detained as foreigners in Odessa for many weeks on the suspicion of espionage preventing them from

${ }^{88}$ Only 9 months were left before the solar eclipse.

89 "Wenn die Akademie nicht gerne dran will, dann kriegen wir das bischen [sic] Mammon von privater Seite. Ich werde mit Habers Hilfe sofort nachdem die Akademie negativen Bescheid gegeben hat, Herrn Koppel anpumpen, der ja das Geld für meinen [sic] Gehalt als Akademiker hergegeben hat. Sollte alles versagen, so zahle ich die Sache selber aus meinem bischen Erspartem, wenigstens die ersten $2000 \mathrm{M}$. Bestellen Sie also nach reiflicher Überlegung nur ruhig die Platten und lassen. Sie die Zeit nicht wegen der Geldfrage weglaufen." EINSTEIN to FreUNDLICH, 7 Dec. 1913, (CPAE), call no. 11 206-1. ${ }^{90}$ See the letter quoted below as well as KIRSTEN \& TREDER (Eds.) [1979] Vol. 2, Documents A 307; B 9, 11.

91 Namely, from EmIl Fischer, vON KRUPP, von Bohlen, and HalbaCh, 3,000 marks each, whose acquaintance with FREUNDLICH had been initiated by FISCHER; see also the copy of Käte Freundlich's letter to L. Pyenson, 29 Apr. 1973, in (CPAE), call no. 11241 .

92 On EINSTEIN's attitude toward experiments in the period, see HENTSCHEL [1992]c.

93 "Sie können sich denken, wie sehr ich mich darüber freue, dass die äusseren Schwierigkeiten Ihrer Unternehmung nun sozusagen überwunden sind. Nicht minder schön ist es, dass sich alle Beteiligten so gut bei der Angelegenheit verhalten haben. Besonders kann ich Planck nicht genug rühmen. [...]." EINSTEIN to FrEUNDLICH, second half of Feb. 1914, (CPAE), call no. 11 207-1, quoted from KLEIN et al. (Eds.) [1993]. 
carrying out their measurements. Moreover, their instruments were confiscated. ${ }^{94}$ But when FreundLICH was allowed on 3 September 1914 to return again to Berlin, his enthusiasm towards verifying the general theory of relativity was undiminished. The astonishingly wide publicity the results of the English solar eclipse expedition at the end of $1919^{95}$ received, which roughly verified relativity theory's prediction of $1^{\prime \prime} .75$ within the margin of error, had only fueled FreUNDLICH's ambitions further. In 1922, 1925-26 and 1929 he again went on expeditions to record light deflections during solar eclipses (see the overview p. 155). Yet, despite carefully choosing the observation site on the basis of local weather statistics, cloudy weather made photographing the field of stars surrounding the eclipsed sun impossible ${ }^{96}$ at Christmas Island on 20 September 1922 and in South Sumatra in 1926.

FreUnDLICH nevertheless won support at the end of 1928 to prepare for another expedition, this time to observe the solar eclipse on 9 May 1929 in Takingeun, North Sumatra. In contrast with the earlier expeditions, it was possible this time to make photographic plates of high quality not only of the fields of stars around the sun, but also the comparison exposures, using the horizontal double camera FreundLICH and his mechanic ERICH STROHBUSCH had especially designed and developed to the highest degree of perfection for the occasion (see the following figures).

The horizontal double camera essentially consisted in two identically constructed horizontal cameras with the very large focal length of $8.5 \mathrm{~m}$ and a $20 \mathrm{~cm}$ aperture, ${ }^{97}$ which were placed approximately at a $25^{\circ}$ angle to each other. Both cameras received the light from the same coelostat, a special

${ }^{94}$ See FrEUndLICH's report to the Preußische Akademie der Wissenschaften of 7 Oct. 1914, (AAW), II-VII-158, sheets 19ff. and PLANCK's letter to EINSTEIN, 19 Mar. 1918, (CPAE), call no. 19 273-1: "Freundlich should only address the Academy with a report describing the circumstances and in which he requests that the Academy take steps with the relevant authorities so that the instruments confiscated in Odessa are returned as soon as possible. I will then do all I can to support this petition." "Freundlich soll sich nur mit einer Eingabe an die Akademie wenden, in welcher er die Verhältnisse schildert und die Akademie bittet, Schritte bei den zuständigen Behörden zu tun, damit die in Odessa beschlagnahmten Instrumente so bald als möglich ausgeliefert werden. Ich werde dann alles tun, um dieses Gesuch zu unterstützen."

95 See Dyson, EdDington \& DAvidson [1920] for the original publication, transcriptions of scientific discussions, etc., in Monthly Notices of the Royal Astronomical Society 80 [1919/20], pp. 96ff., in Observatory 42 [1919/20] pp. 119-122 as well as in the Proceedings of the Royal Society, London 97 [1920], pp. 72ff. and CLARK [1973], pp. 168f., EARMAN \& Glymour [1980]b, and MOYer [1979] on their reception. See in addition, p. 62 of this article for FREUNDLICH's subsequent criticism of EDDINGTON's results.

96 See, e.g., Freundlich [1923]b, KLÜBER [1926].

97 This was by far the largest focal length used up to that time to investigate the deflection of light; see v. KLÜBER [1960] p. 67. 


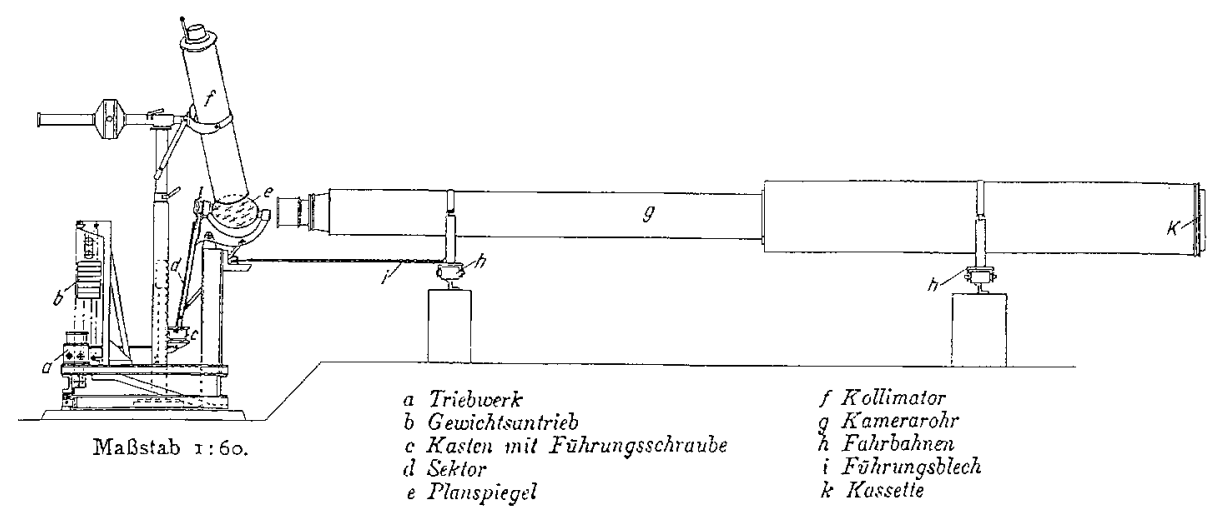

Figure 3. The Potsdam horizontal double camera with coelostat and driving mechanism, schematic sideview, from FreundLich [1930]a p. 317. See also FreundLich, v. KLÜBER \& V. BRUNN [1931]b p. 7 ,

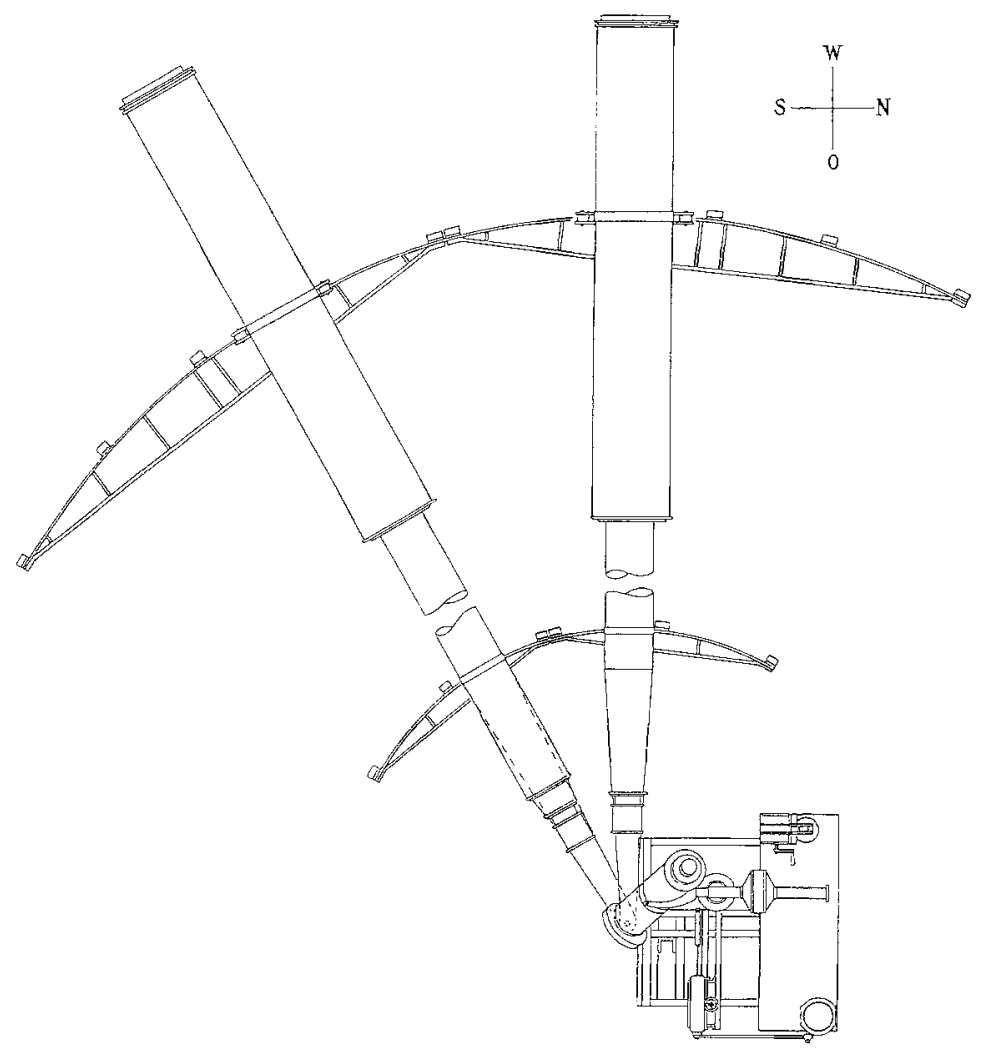

Figure 4. The Potsdam horizontal double camera, 1929; schematic view from above, scale approximately 1:50 (the two extended telescopes are $8.5 \mathrm{~m}$ in length), from FREUNDLICH, v. KLÜBER \& v. BRUNN [1931]b Plate I or [1931]a p. 177. 


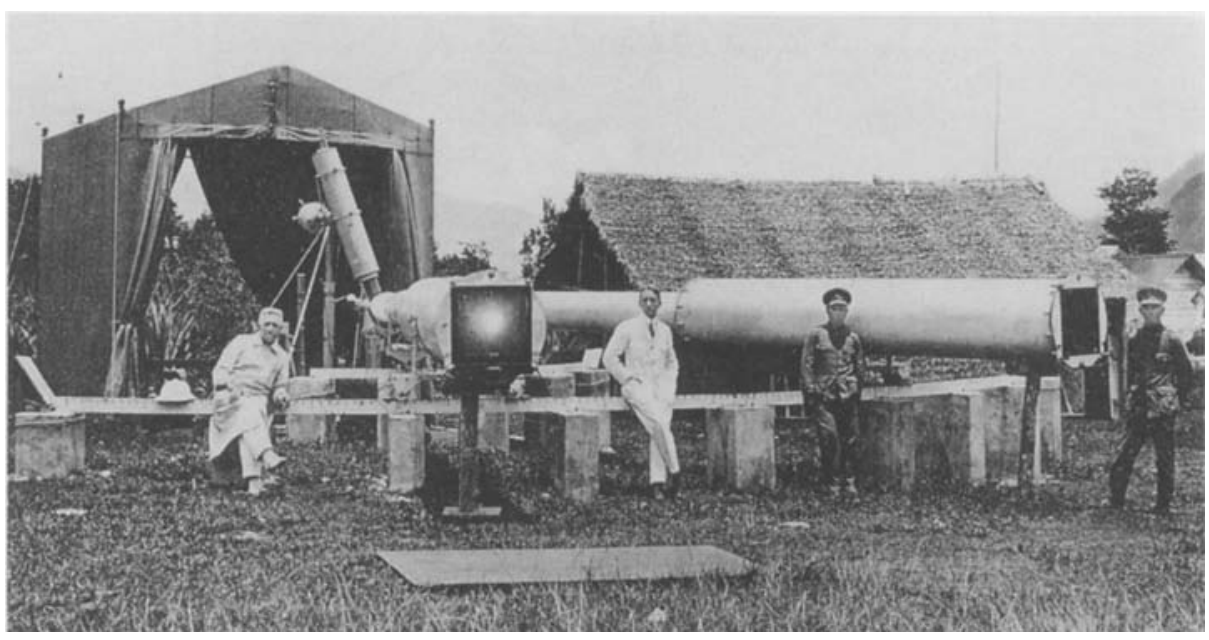

Figure 5. FREUNDLICH in front (center) of the horizontal camera for measuring the deflection of light in the sun's gravitational field during the solar eclipse in Sumatra, 1929; from Freundlich, v. KLÜBer \& v. BRUnN [1931]b Plate II or [1931]a p. 176.

construction by the Zeiss company, in which special attention was devoted to the precision of the automatic driving mechanism, which was controlled electromagnetically by a chronometer, to assure the sharpest possible stellar images. ${ }^{98}$ Photo plates of the considerable size of $45 \mathrm{~cm} \times 45 \mathrm{~cm}$ were attached at the focal plane of both horizontal cameras which covered a field of stars $3^{\circ} \times 3^{\circ}$ with a scaling of $1^{\prime}=2.5 \mathrm{~mm}$. One of the two cameras was pointed at the eclipsed sun and the surrounding field of stars, the other at a comparison field. In order to be able to analyse possible changes in scale on the photo plates, a thermally isolated collimator with an imprinted rectangular grating was attached in front of the coelostat mirror $30 \mathrm{~cm}$ in diameter, ${ }^{99}$ in the path of the rays, ${ }^{100}$ so that the photographic plates had a regular grid imprinted on them. The same procedure was repeated a few months later with the same field of stars at night under as identical conditions as possible - one observer (HARALD V. KLÜBER) thus had to stay on location with the instruments until the end of 1929. At this time, exposures were also made on the reverse side of a glass plate - the resulting mirror-image photographs could then be placed directly on top of those of the fixed-star fields for comparison, so that only differential measurements of deviating star positions, and no absolute measurements of star

98 See v. Klüber [1932], Freundlich, v. Klüber \& v. BRUnN [1931]b pp. 9-10 or $[1931]$ a p. 178.

99 On the coelostat, see FreundLICH, v. KLÜBER \& v. BRunN [1931]a pp. 178-179.

${ }^{100}$ See, e.g., FREUNDLICH, v. KLÜBER \& v. BRUNN [1931]b pp. 11-14 or [1931]a p. 180. 


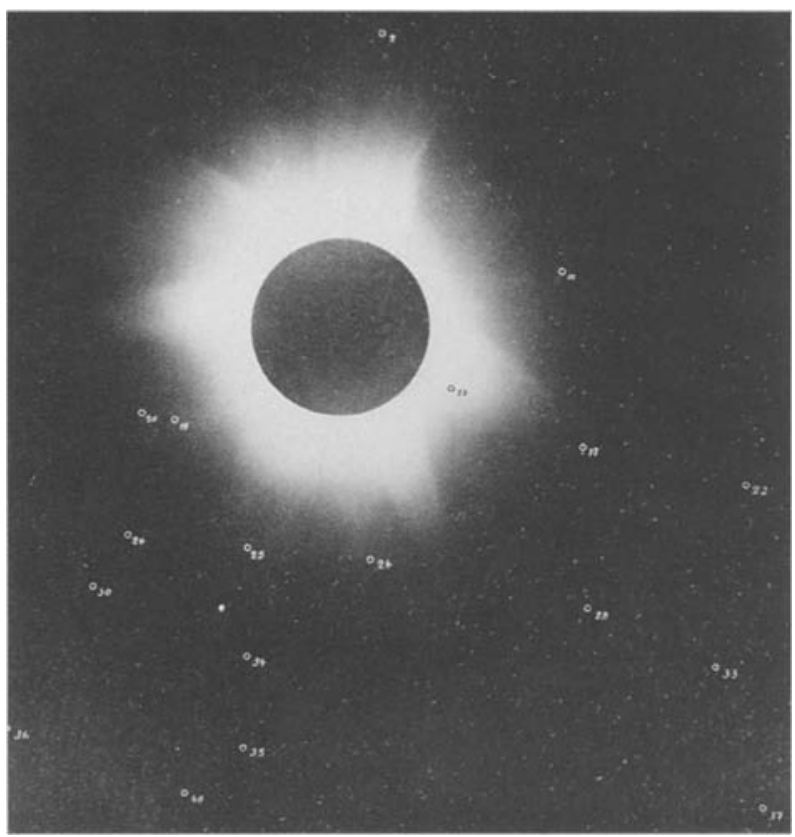

Figure 6. One of the four photographs made in 1929 of the eclipsed sun with corona and (numbered) surrounding stars, from FREUNDLICH, v. KLÜBER \& V. BRUNN [1931]b Plate I or [1931]a p. 183.

positions, then needed to be taken. ${ }^{101}$ Out of the micrometrically determined variations in the stellar positions (eclipse glass plate) or (night glass plate), the shifts (eclipse glass plate) were derived through the following simple calculation: ${ }^{102}$

$$
\Delta x_{i}=\left(X_{F}-X_{G}\right)_{i}-\left(X_{N}-X_{G}\right)_{i} .
$$

In addition to this horizontal double camera, in Takingeun FREUNDLICH also used a separate parallactically mounted astrograph with a focal length of $3.4 \mathrm{~m}$ and a $20 \mathrm{~cm}$ aperture which was designed for photographs $7.5^{\circ} \times 7.5^{\circ}$ in size with a scale of $1^{\prime}=1 \mathrm{~mm}$, which could record up to 100 bright stars, and which were moreover sharply focussed right to the edge of the image. ${ }^{103}$ This astrograph was first focussed on the eclipsed sun and then, without changing the

101 The accuracy of determining shifts micrometrially in the position of stars from $\Delta x_{i}$ to $\Delta y_{i}$ could thereby be significantly improved, since micrometric errors accumulate in addition to the systematic errors for larger distances. Cf. also FreUNDLICH [1932] pp. 297f. for photographic problems in light deflection measurements.

102 See e.g., FREUNDLICH \& V. BRUNN [1933], p. 222.

103 All figures from FREUNDLICH [1930]a pp. 314-315. 
photographic plate, focussed on a comparison field. Three such double exposed plates could be obtained altogether during the eclipse. The reason behind this was that the measurements of the stellar positions from the comparison field could provide corrections in scale for the photographic plate. Unfortunately, this method did not yield any usable results - presumably the rapid repositionings performed during the eclipse of only a few minutes caused mechanical tensions to form within the instrument which led to distortions in the comparison field image that could no longer be calculated out afterwards. ${ }^{104}$

The complicated interpretation of the results, which included by itself 100,000 individual micrometric measurements, and just as many tedious calculations, could only be completed by 1930 , despite the acquisition of additional help for the calculation work (LENA BoRCHHEIM). The photographic plates were first measured micrometrically with an especially designed measuring device, ${ }^{105}$ in a workshop at the Astrophysikalisches Observatorium Potsdam. The thus acquired raw data was subjected to complicated algebraic calculations with which the influence of the position of the plate in the measuring instrument (1) and in the camera (2), not only related to the different tilts (2a) but also to a change in the focal length (2b), incidental astronomical influences such as aberration (4) and refraction (5), and not least the possible physical influence of light deflection in the gravitational field (3), were to be computed. ${ }^{106}$ FreUNDLICH, $v$. KLÜBER and v. BRUNN interpreted the raw data obtained from equation (3) using the following equation for the $x$ or $y$ components of the stellar coordinates (difference: daytime minus night photo):

$$
\begin{aligned}
& \Delta x=\underbrace{a+b y}_{1}+\underbrace{p x^{2}+q x y}_{2 a}+{ }_{2 b}^{S x}+\underbrace{E x / r^{2}}_{3}+A x+R x \\
& \Delta y=\underbrace{a-b x}_{1}+\underbrace{p x y+q y^{2}}_{2 a}+{ }_{2 b}^{S y}+\underbrace{E y / r^{2}}_{3}+{ }_{4}^{A y}+{ }_{5}^{R y}
\end{aligned}
$$

$a, b, p, q, S$ and $E$ are the unknowns to be determined through the least squares calculations; $A$ and $R$ are to be individually calculated from the data attached to each of the photos, such as temperature, barometer reading, exposure time, as well as from the coordinates of the stars at the time of each photo; $1-5$ refer to the above-described possible geometric and physical influences on the stellar shifts. The separation of the two unknowns $S$ and $E$ posed a particular difficulty in this optimization using 36 equations for the 18 stars under examination, since

104 See in this regard Freundlich, v. KLÜbER \& V. BRUNN [1933] as well as v. KLÜBER [1960] pp. 70-71, which describes how shifts of the focal plane of already $1 / 100^{\text {th }}$ of a millimeter are completely sufficient to produce such undesirable effects.

105 See in this regard HerRmann \& Freundlich [1931], Meyer [1930].

106 See regarding the terms (1) to (5) the following pair of equations; see also FREUNDLICH, v. KLÜBER \& v. BRUNN [1931]b pp. 25-32, [1931]a pp. 173f., FreUNDLICH [1955]a pp. 243f., [1960] pp. 124ff. For EDDINGTON's interpretation, see MOYER [1979] pp. $73-77$. 
as the central part of the plate is taken up by the moon or by the eclipsed sun and its surrounding corona, stars only appear when distance $r$ starts to become significantly larger than 1, and thus the coefficients of $E$ become correspondingly smaller than 1 . As a result, the weight of determining $E$ becomes less, whereas that of $S$, whose coefficient increases sharply in relation to the constantly rising number of stars as you move away from the rim, becomes correspondingly greater. [. . . thus the heavily weighted $S$ has the tendency to inflate itself from the available systematic shifts of stellar [coordinates] during the eclipse compared against the night [photograph] at the expense of the main unknown $E$ of small weight, so that the latter runs the risk of ending up being too small. ${ }^{107}$

FreUNDLICH could specify this mathematical coupling of the two unknowns $S$ and $E$ in later papers according to the following relation (6): ${ }^{108}$

$$
\Delta E \simeq r^{2} \Delta S
$$

that is, with an average stellar distance of $5 r$, each error in determining $S$ has a 25-fold effect on the resulting light deflection value as compared to at distance $r$. Due to this relation, great weight was given at the Potsdam expedition to the independent determination of scale values derived from an interpretation of the stellar positions, which had become feasible through comparing the regular grid imprinted on the horizontal camera plates.

A comparison of the rulings imprinted on the photographic plates directly after the eclipse revealed:

The difference between the actual length and the proper length in the images on the two plates [...] composed of segments of a distance of ten grating rulings, exceed the total of $\pm 5 \mu \simeq 0^{\prime \prime} .1$ only very rarely."109

107 "da der zentrale Teil der Platte von dem Mond bzw. von der verdunkelten Sonne und der sie umgebenden Korona eingenommen wird, treten Sterne erst dann auf, wenn der Abstand $r$ anfängt, merklich größer als 1 und damit die Koeffizienten von $E$ entsprechend kleiner als $1 \mathrm{zu}$ sein. Infolgedessen wird das Gewicht der Bestimmung von $E$ klein, dagegen das von $S$, dessen Koeffizient mit der nach dem Rande ständig wachsenden Sternzahl stark zunimmt, entsprechend groß. [...] so hat das mit großem Gewicht behaftete $S$ die Tendenz, sich aus den vorhandenen systematischen Verschiebungen der Sterne Finsternis gegen Nacht, auf Kosten des mit kleinem Gewicht behafteten Hauptunbekannten $E$ zu bereichern, so daß diese zu klein herauszukommen Gefahr läuft." FreUndLICH, v. KLÜBER \& v. BRUNN [1931]a p. 175; see also FREUNDLICH \& v. BRUNN [1933] pp. 223-229 and FREUNDlich, v. KLÜBER \& v. BRUNN [1933] pp. B-14-B-16.

108 See Freundlich \& GleissberG [1935], Freundlich \& Ledermann [1944], MATTIG [1956] pp. 181f.

109 "Die Differenzen zwischen Ist-länge und Soll-länge in den Abbildern auf den zwei Platten [...] gebildet für Teilstücke von zehn Gitterstrichabständen, übersteigen den Betrag von $\pm 5 \mu \simeq 0^{\prime \prime}$, 1 nur ganz ausnahmsweise." FrEUNDLICH, v. KLÜBER \& v. BRUNN [1931]a p. 182; see also [1931]b pp. 27-30. 
Through this regular grid comparison it was demonstrated above all, that other conceivable systematic sources of error, such as a contraction of the exposed photographic plate while the emulsion was drying, caused by the extremely uneven exposure of different areas ${ }^{110}$ were not present.

That the distances between the grating lines were nonetheless subject to negligible yet irregular fluctuations as well, is illustrated particularly clearly in the following figure, in which also the shifts of stellar locations induced by the light deflection effect are included in the same scale:

The comparison of the positions of the stars during the solar eclipse with the normal positions of these stars on the night photograph produced by $\mathrm{v}$. KLÜBER of the same field of stars was first made without taking into account the 'Einstein effect' $\sim E$, in order to obtain in particular the difference in scale values of $S$ :

$$
\Delta x=a+b y+p x^{2}+q x y+S x ; \quad \Delta y=a-b x+p x y+q y^{2}+S y,
$$

The resulting shifts $\Delta x$ and $\Delta y$ were then in a second series of calculations freed from the influence of aberration and refraction from the earth's atmosphere, which had to be separately computed for each photograph and for each stellar coordinate, ${ }^{111}$ then, by incorporating the term $E x / r^{2}$ in equation (4), a final calculational optimization of the observed field of stars was carried out. The two following figures illustrate the results of this laborious, two-step data evaluation procedure; comparing them shows that the shifts of the stellar locations without taking into consideration the relativistic light deflection in the sun's gravitational field produces a strong scattering of the distribution of displacement vectors, ${ }^{112}$ while incorporating the relativistic correction in the form of the terms $E / r_{i} \cdot x_{i} / r_{i}$ leads to an approximately centrally symmetrical distribution of the orientations of the displacement vectors, the totals of which, in addition, fall with the increase in distance $r$ from the sun's face according to the $1 / r$ law.

For the deflection angle immediately at the sun's rim, which could not be measured practically because of the brightness of the corona but was theoretically particularly easily calculable, out of the analysis of the four plates FREUNDLICH and his collaborators arrived at the values: $2^{\prime \prime} .25 ; 2^{\prime \prime} .17 ; 2^{\prime \prime} .61$; $1^{\prime \prime} .81$; that is, averaged out: $2^{\prime \prime} .24 \pm 0^{\prime \prime} .10$ (instead of $1^{\prime \prime} .75$ according to relativity theory), by extrapolating from the final measurements of the 18 relevant stars following the hyperbolic law required by relativity theory. ${ }^{113}$ It should be

110 A round dark center versus a light background; see in this regard the studies by Ross [1920] in Kodak's Eastman Laboratory.

111 See on this FrEUNDLICH, v. KLÜBER \& v. BRUNN [1931]b p. 51.

112 The displacement vectors 19 and 20 , for instance, are almost perpendicular to the directly neighboring displacement vectors 26 and 30; see furthermore FREUNDLICH, v. KLÜBER \& V. BRUNN [1931]a p. 186.

113 See v. KLÜber [1929], FreUndlich, v. KLÜber \& v. BrunN [1931], 


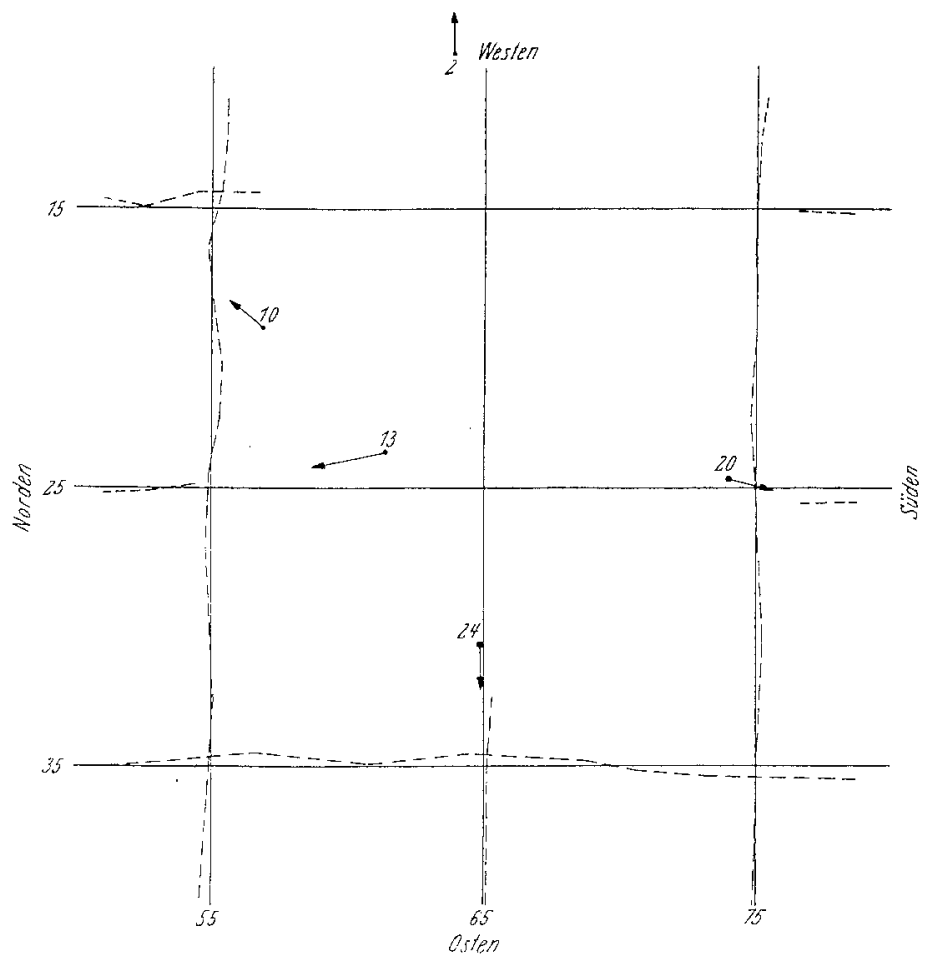

Figure 7. Differential comparison of the gratings of two photographic plates. For comparison the displacement vectors resulting from light deflection for a few stars are recorded in the same scale. Scale of the original picture: $1 \mathrm{~mm}=0^{\prime \prime} .17$. From FREUNDLICH, v. Klüber \& v. BRUNN [1931]b Plate VI or [1931]a p. 182.

noted here that the closest suitable star was approximately 1.5 solar radii away from the sun's center, the farthest 7.5 solar radii. Already in the intermediate area of about 5 solar radii, substantial deviations from the predictions of relativity theory were apparent in the measured deflections, with a tendency toward greater values than expected. EINSTEIN exhibited some irritation at the large discrepancies in the values derived from the four plates for $E$ (between $1^{\prime \prime} .6$ and $2^{\prime \prime} .6$ with an average error for each individually determined value of $\left.\pm 0^{\prime \prime} .2\right)$. At this, Freunduich attempted to placate him:

The apparently too large fluctuation of the values for $E[\ldots]$ is actually not unduly large. Deviations from the mean value up to twice the amount of the average error are normally always to be reckoned with, this thus means in our case up to $0^{\prime \prime} .40$. [..]. A dependence of the value of $E$ upon the lengths of the exposure: $40 \mathrm{sec}$,

Freundlich [1931]; see also, e.g., TrÜMPler [1932], Courvoisier [1932], Danjon [1932] among others for different data reductions. 

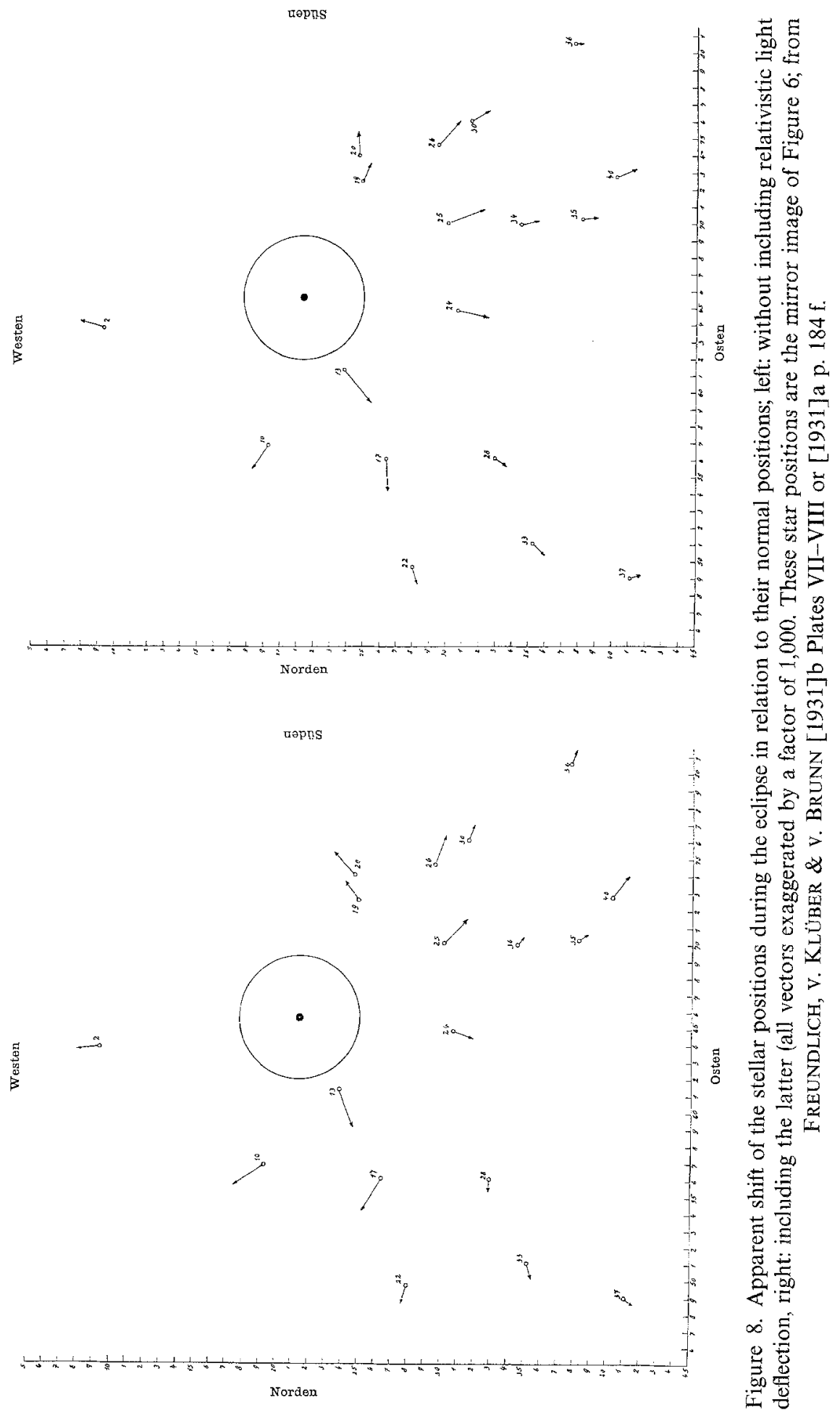


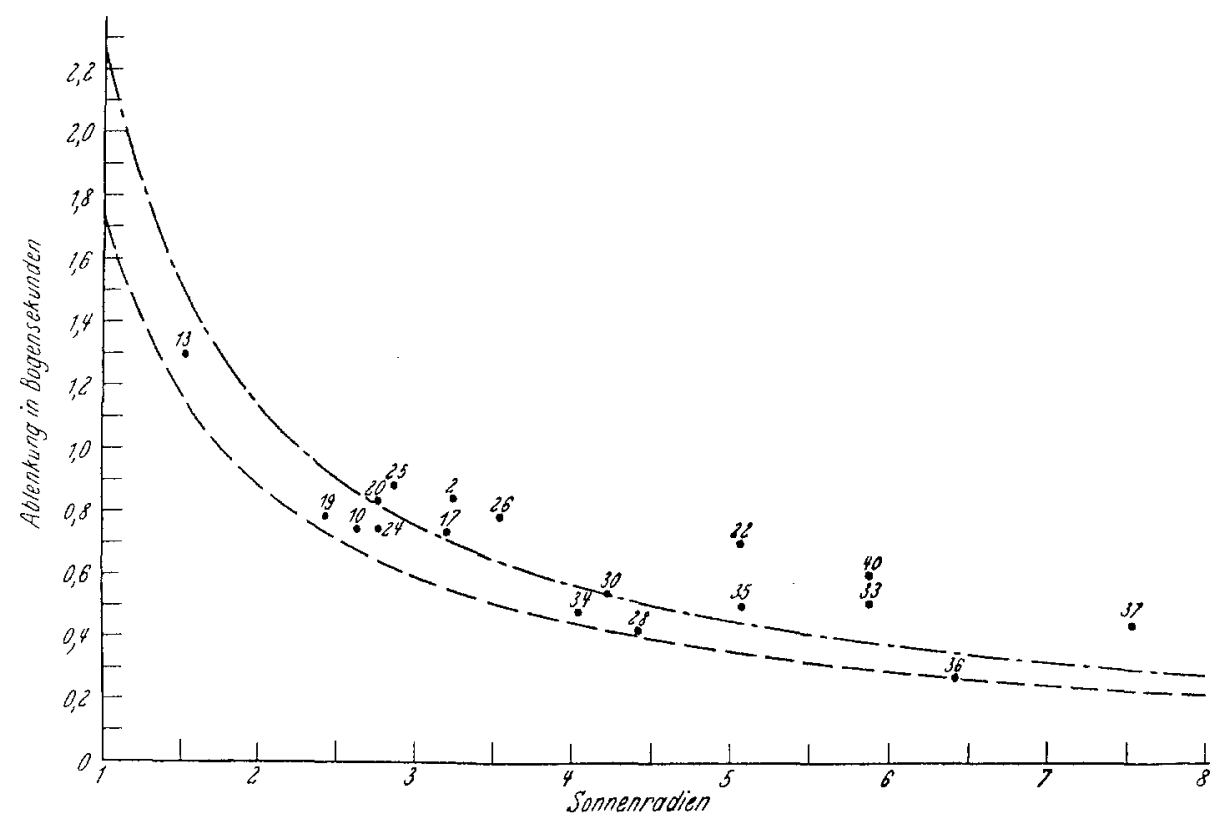

Figure 9. The shifts of 18 star positions plotted in relation to their distance from the sun's center (mean values from the 4 plates of the eclipse field), from FrEUNDLICH, v. KLÜBER \& V. BRUNN [1931]b p. 36 or [1931]b p. 191; see also [1931]a p. 35 for the separate analysis of each photographic plate.

$90,60,40 \mathrm{sec}$. is not evident, and equally unlikely is a dependence upon the sequence of the photographs. It would, of course, have been conceivable that as the phase of the eclipse proceeds, the coelostat mirror would progressively deform and produce the same errors. This also is not apparent. ${ }^{114}$

$\mathrm{He}$ also rebuffed ErNstein's inquiry on the possible influence of anomalous refraction from the earth's atmosphere, referring to TRÜMPLER's estimate of this effect as minimal $\left(<0^{\prime \prime} .001\right){ }^{115}$ though this did not ultimately convince EINSTEIN. ${ }^{116}$

114 "Die anscheinend zu grosse Schwankung der Werte $E[\ldots]$ ist aber in Wahrheit nicht über Gebühr gross. Man hat normaler Weise mit Abweichungen vom Mittelwert bis zum doppelten Betrag des mittleren Fehlers immer zu rechnen, d.h. also in unserem Falle bis zu $0^{\prime \prime}, 40$. [..]. Eine Abhängigkeit des Wertes von $E$ von der Dauer der Expositionen: 40 sek., 90, 60, 40 sek. tritt nicht zu Tage und ebensowenig eine Abhängigkeit von der Reihenfolge der Aufnahmen. Es wäre ja denkbar gewesen, dass mit fortschreitender Phase der Finsternis der Coelostatenspiegel sich fortschreitend deformierte und gleiche Fehler erzeugte. Auch das zeigt sich nicht." Freundlich to EINSTEIN, 9 June 1931, (CPAE), call no. 11 171-1.

115 Einstein to FreundLich, 27 June 1931, (CPAE), call no. 11172 and FreundLICH to EINSTEIN, 29 June 1931, (CPAE), call no. 11173.

116 See Einstein to FreundLich, 3 July 1931, (CPAE), call no. 11 174; see also 
What is remarkable about FREUndLICH's, v. KLÜBER's and v. BRUnN's results is the quite small error they claimed for their unexpectedly high result, aside from the considerable discrepancy to the value attributed by the relativity theory to the light deflection at the sun's rim: an error of only $0^{\prime \prime} .10$. This was far less of a margin of error than all the observers before them had indicated for their results and also far lower than the fluctuation of the four individual values of the four plates $\left(0^{\prime \prime} .40\right)$, from which they had obtained their results through averaging. Their interpretation culminated with the conclusion:

There seems to be no doubt possible, therefore, that our series of measurements does not agree with the value $1^{\prime \prime} .75$ claimed by the theory. The question of whether our amount could be invalidated by a systematic error, cannot be finaily determined as long as the possibility remains that unknown infiuences affect the results. [...]. In the meantime, the conclusion thus cannot be avoided that the deflection of light in the proximity of the sun is found to be larger than the value predicted by relativity theory. ${ }^{117}$

These results were corroborated in a treatment of the data of the comparison field which were evaluated using exactly the same method as they had used before for the reduction of the eclipse photographs. This check offered no indication of systematic effects, specifically, no radially symmetric shifts, and no anomalous refraction phenomena in the comparison field. The resulting shift vectors were very much smaller than the shifts in the eclipse field. ${ }^{118}$

Since FreUNDLICH's findings contradicted previous solar eclipse expedition results, Freunduich and his collaborators ended their analysis with a discussion of these earlier results. Their essential point on EDdington and CROMMELIN's 1919 measurements, as well as on CAMPBELL and TRÜMPLER's 1922 data $^{119}$ was

FREUNDLICH to EINSTEIN, 8 July 1931, in which FREUNDLICH characterized EINSTEIN's estimate as too rough, and EINSTEIN's reply to FrEUNDLICH, 16 July 1931, (CPAE), call no. 11177 .

117 "Es scheint darum kein Zweifel darüber möglich, daß unsere Messungsreihe mit dem von der Theorie behaupteten Betrag 1",75 nicht verträglich ist. Die Frage, ob unser Wert durch einen systematischen Fehler verfälscht sein mag, läßt sich endgültig nicht entscheiden, solange überhaupt die Möglichkeit besteht, daß unbekannte Einflüsse die Resultate beeinflussen. [...]. Vorläufig läßt sich also die Schlußfolgerung nicht umgehen, daß die Lichtablenkung in der Nähe der Sonne größer gefunden wird als der von der Relativitätstheorie vorausgesagte Wert." FreUndLICH, V. KLÜBER \& V. BRUNN [1931]a pp. 187f.

118 See FreundLich, V. KLÜBER \& v. BRUNN [1931]b pp. 38-40 and their plate XII, [1931]a pp. 190-192, v. BRUNN \& v. KLÜBER [1937].

119 See Dyson, Eddington \& Dayidson [1920], Campbell \& Trumpler [1923/24], [1928]. 
hard to swallow, since it amounted to again calling into question the communis opinio, formed in the last 12 years through innumerable media reports of the time, that EdDington and Crommelin's expedition clearly confirmed the general theory of relativity:

The first determination of light deflection by the English expedition in 1919 already did in reality provide an unambiguously larger value for $E$ than relativity theory had predicted. Those observed data by the English expedition of unquestionably the greatest weight, namely those obtained with the four-inch lens with a $6 \mathrm{~m}$ focal length, yielded $E=1^{\prime \prime} .98$ from seven plates each with seven stars close to the sun. But this divergence was not deemed realistic when the Lick expedition some years later arrived at exactly the theoretically predicted value from their measurements. But it can be shown that this total confirmation of relativity theory has been feigned through an error in the reduction procedure, and that through a correct reduction of the value, $E=2^{\prime \prime} .2$ results. Furthermore, it can be shown that the first English observations also support a light deflection value lying closer to $2^{\prime \prime} .2$ which is still above the then calculated value $E=2^{\prime \prime} .00 .^{120}$

FREUNDLICH and his collaborators further strengthened their argument elsewhere by referring to the quasi-linear coupling of the scale value $S$ and the EINSTEIN value $E$ in the least squares calculations (see p. 33f.), which they were the very first to work out clearly, because the double horizontal camera enabled them to include an independent determination of the scale value in their measurements:

That is why all measurements of light deflection up to now, with the exception of the observations made with our horizontal camera, lack the methodical basis guaranteeing the quantitative reliability of their determinations. ${ }^{121}$

They also presented this provocative revision of earlier measurements graphically, in a diagram in which they recorded the newly computed shifts on the

120 "Die erste Bestimmung der Lichtablenkung durch die englische Expedition im Jahre 1919 lieferte in Wahrheit schon einen unzweideutig größeren Wert für $E$ als die Relativitätstheorie vorausgesagt hatte. Diejenigen Beobachtungsdaten der englischen Expedition, welche das unbedingt größte Gewicht haben, nämlich die mit der vierzölligen Linse von $6 \mathrm{~m}$ Brennweite gewonnenen, ergaben $E=1^{\prime \prime}, 98$ aus sieben Platten mit je sieben sonnennahen Sternen. Es wurde aber diese Abweichung nicht für reell erachtet, als die Lick-Expedition einige Jahre später genau den theoretische vorausgesagten Wert aus ihren Messungen erschloß. Es läßt sich aber zeigen, daß diese restlose Bestätigung der Relativitätstheorie durch einen Irrtum in dem Reduktionsverfahren vorgetäuscht worden ist und daß bei richtiger Reduktion der Wert $E=2^{\prime \prime}, 2$ resultiert. Ferner läßt sich zeigen, $\mathrm{da} ß$ auch die ersten englischen Beobachtungen für einen Wert der Lichtablenkung sprechen, der noch oberhalb des damals errechneten Wertes $E=2^{\prime \prime}, 00$ näher am 2",2 liegt." Freundlich, v. KLÜBer \& v. BrUnN [1931]a, p. 194; see also [1931]b pp. $40-45$.

121 "Darum fehlt allen bisherigen Messungen der Lichtablenkung mit Ausnahme der Beobachtungen mit unserer Horizontalkamera die methodische Grundlage ihrer quantitativ sicheren Bestimmung." FreUndLICH, v. KLÜber \& v. BRUnN [1933] p. B 27. 


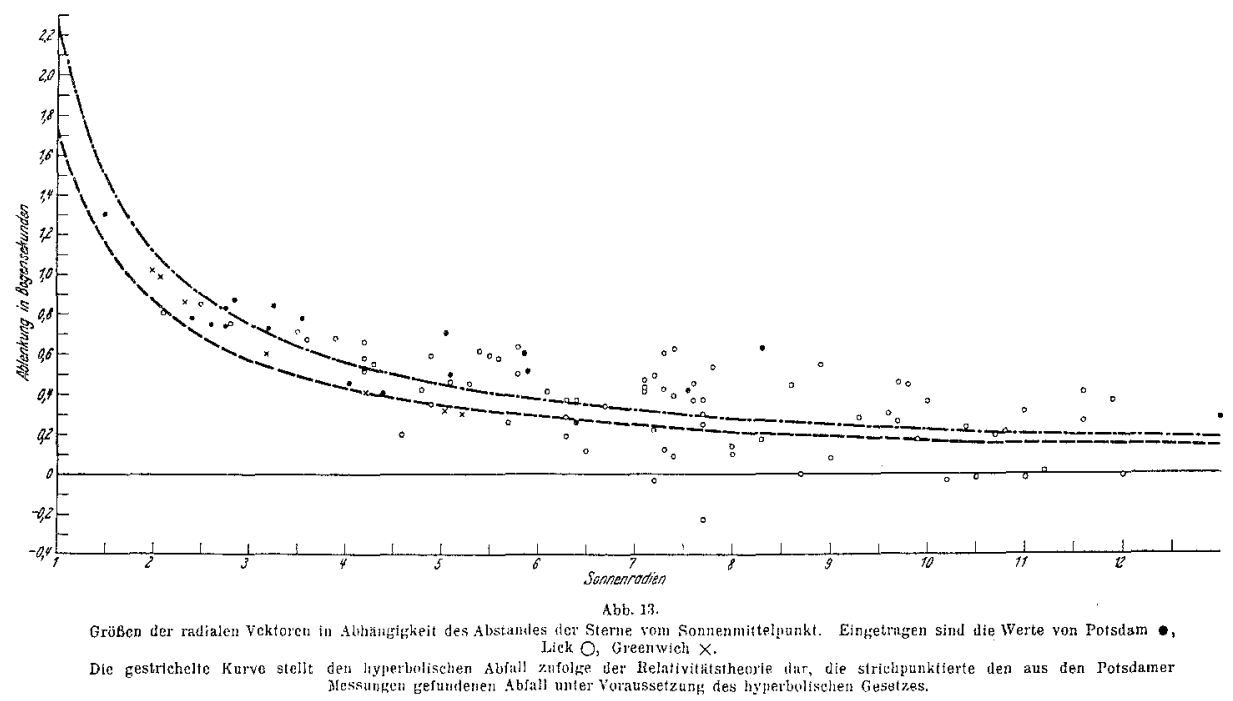

Figure 10. Comparison of light deflection results of the English (1919), American (1922), and German (1929) expeditions, from FREUNDLICH, v. KLÜBER \& v. BRUNN [1931]b p. 43 or [1931]a p. 197.

basis of the previously published raw data from the English, American, and their own expedition, in relation to the distance from the sun's disk (see Figure 10).

FREUNDLICH's interpretation of the data naturally did not remain uncontested: LuDENDORFF, and independently from him also TrüMPLER, pointed to the large source of error caused by the asymmetrical distribution of bright stars near the edge of the sun, while JACKSON suspected an error in the determination of the scale value $S .{ }^{122}$ Thus FreUndLICH's results were also not spared from what he had done on his part with the data of other observers - they were reanalysed by other experts with different reduction methods. ${ }^{123}$ Besides, it was presumably of some significance to his colleagues in considering FREUNDLICH's daring theses, that he had already become involved in a bitter controversy in 1915-16, at which time blood had flowed. In the archives of the Lick Observatories there is a translation by CAMPBELL in October 1931 of an article of the

122 See JACKSON [1931] as well as criticism thereof by LUDENDORFF [1932]a col. 322.

123 See Ludendorff [1932]a, Freundlich, v. KLÜBer \& v. BrunN [1932], TrÜMPLER [1932], DANJON [1932], JACKSON [1931], FREUNDliCh \& v. BRUNN [1933] pp. 232-233 (versus TRÜMPLER [1932]); a (naturally biased) overview of the measurements up to and including 1929 in DYSON \& WOOLLEY [1937] chapter 7; more recent reviews include, e.g., MATTIG [1956], Mikhailov [1959] and v. KLÜBER [1960], WiLL [1989] pp. $79 \mathrm{ff}$. 
Table 4. Recalculations of the light defiection value at the sun's rim from the Potsdam data of 1929 by various other astronomers

\begin{tabular}{lll}
\hline Astronomer & Date & $\begin{array}{l}\text { Recalculation of } \\
\text { light deflection at } \\
\text { the sun's rim from } \\
\text { Potsdam } 1929 \\
\text { data }\end{array}$ \\
\hline JACKSON & 1931 & $1^{\prime \prime} .98 \pm 0^{\prime \prime} .20$ \\
TRÜMPLER & 1932 & $1^{\prime \prime} .75 \pm 0^{\prime \prime} .19$ \\
LUDENDORFF & 1932 & $1^{\prime \prime} .90-2^{\prime \prime} .00$ \\
DANJON & 1932 & $2^{\prime \prime} .06$ \\
MIKHAILOY & 1956 & $1^{\prime \prime} .96 \pm 0^{\prime \prime} .11$ \\
\hline
\end{tabular}

same date by Hugo von Seeliger against Einstein, which Campbell had surely only prepared, to share with his English-speaking colleague v. SEELIGER's vehement denunciations of Freundlich. A letter by Campbell to TrüMPLER is in the same vein, in which he reports on FreUndLICH's attacks on their common researches of 1923-24 and 1928 and then continues:

Confidentially I am also telling Dr. Prichett [President Emeritus of the Carnegie Foundation] that Dr. Freundlich was compelled to resign from the Berlin-Babelsberg Observatory about the year 1915 by its Director, Hermann Struve, because of Freundlich's trickery and dishonesty in scientific matters, as shown up by Seeliger in The [Astronomische] Nachrichten Vol. 202, page 83. To give you the right angle on Freundlich, I advise you to read that article, if you have not already done so. The whole incident was described to Dr. Moore and others here a fortnight ago by Professor Georg Struve, an astronomer in Berlin university and Babelsberg observatory, who has been making observations with the Lick telescope during the past three months. He also remarked that Freundlich has no standing whatever with German astronomers. ${ }^{124}$

Though the astronomical community remained sceptical, EINSTEIN nevertheless did consider in 1931 a possible correlation between the anomalies claimed by FREUNDLICH and his attempts at a unified theory of gravitation and electricity, which also brought with it modified field equations but only briefly: ${ }^{125}$

In the last few days I have found strong indications that the general theory of relativity, based upon a parailel structure, cannot be reconciled with the facts. Thus, from a theoretical standpoint, an exact validity of the old equations becomes very likely. ${ }^{126}$

124 CAmpbell to Trümpler, 21 Oct. 1931, copy in (CPAE), call no. 11235.

125 For an overview, see PAIS [1982] sec. 17.

126 "Ich habe in den letzten Tagen gewichtige Anzeichen dafür gefunden, dass die auf der Parallelstruktur beruhende allgemeine Relativitätstheorie mit den Tatsachen nicht 
And a week later:

The old gravitation equations are not only based upon the relativity postulate, which on its own a discerning person could hardly doubt, but also on the assumption of a relatively far-reaching separability of the law of gravitation from the law of the total field. This latter assumption has no backing. It is precisely for this reason that an accurate consideration of the bearing of the experimental results is of such great importance. ${ }^{127}$

Unfortunately, EINSTEIN's mathematical speculations never came to the stage where a comparison between theory and observation, possibly through prediction of a modified deflection of light, could be made. ${ }^{128}$ In 1932 EINSTEIN seems to have then adopted the majority opinion and saw in FreUNDLICH's findings the result of an "erroneous calculation of the experimental results [...]. Through correct calculation, a good conformity with the theory is again reached." 129

How bitter the fighting was at the beginning of the 1930's over the 'correct' interpretation of the Potsdam data, is also shown, for example, in the debate between LUdENDORFF and FreUNDLICH in 1932 in the Astronomische Nachrichten (see Fig. 11).

FREUNDLICH and v. BRUNN finally pointed out that the mechanical and optical precision of the instruments would have to be very much increased (i.e., the relative changes in focal length $<10^{-6}$ ) and that future plates would have to have a (for that time completely utopian) scale accuracy of $\Delta S<1 / 100,000$ to produce suitable data. ${ }^{130}$ Finally, v. BRUNN and v. KLÜBER were even able to

vereinbar ist. Es wird somit vom theoretischen Standpunkt aus eine exakte Gültigkeit [sic] der alten Gleichungen sehr wahrscheinlich." EINSTEIN to FreundLICH, 27 June 1931, (CPAE), call no. 11172.

127 "Die alten Gravitationsgleichungen beruhen nicht nur auf dem Relativitätspostulat, welches an sich kaum von einem einsichtsvollen Menschen bezweifelt werden dürfte, sondern auch auf der Voraussetzung von einer verhältnismässig weitgehenden Abtrennbarkeit des Gesetzes der Gravitation vom Gesetze des Gesamtfeldes. Diese letztere Voraussetzung ist durch nichts gesichert. Gerade deshalb ist die genaue Ueberlegung der Tragweite der experimentellen Ergebnisse von so grosser Bedeutung." EINSTEIN to FreUNDLICH, 3 July 1931, (CPAE), call no. 11174.

128 See, for example, EInSteIn to Tolischus, 9 Apr. 1930, (CPAE) call no. 11 163: "But consideration of the consequences of this theory is not yet far enough advanced to permit a comparison of the theory with observation" ("Berechnung der Konsequenzen dieser Theorie ist aber noch nicht weit genug fortgeschritten, um einen Vergleich der Theorie mit der Erfahrung zu ermöglichen").

129 "fehlerhafter Berechnung der Versuchsresultate [...]. Bei richtiger Rechnung kommt wieder gute Übereinstimmung mit der Theorie heraus." See EINSTEIN to L. MAYR, 23 Apr. 1932, (CAPE), call no. 11179.

130 See FreUNDLICH \& V. BRUNN [1933]. 


\section{Bemerkung zu Herrn Ludendorffs Ausführungen in Nr. 5848 dieser Zeitschrift.}

Von E. Freundlich, H. v. Klüber und A.v. Brunn.

Die Feststellungen Herm Ludendorffs in AN 5848 , | ausführlich behandelt. In eine nähere Diskussion der letzten Sp. 321 u. ff., sind im Grunde genommen nichts anderes als eine dankenswerte, aber nicht allzu dringliche Probe darauf, da $\mathrm{B}$ unsere Rechnungen im wesentlichen exakt sind. Die Vorstellung, man solle den Nullpunkt auf den Platten, um die angedeutete Unstimmigkeit zu beseitigen, in der einen Halfte nach Osten, in der anderen Hälfte um den gleichen Betrag nach Westen verschieben (Fall $\mathrm{tb}$, Spalte 328 ), stellt allerdings bei der Starrheit der Platten einen logischen Widersinn dar $\left.{ }^{1}\right)$. Wenn möglich noch unbegreiflicher ist die Zumutung (erster Teil der Arbeit bis Sp. 327 Mitte), daB man die 5 wichtigsten Sterne einfach weglassen'sollte - wichtig, weil sic verhindern, da $B$ das ganze Sternield nur auf einer Seite der Sonne zu liegen kommt. Herr Ludendorf hat ja offenbar selbst bemerkt, da $B$ dann die Reduktionsaufgabe praktisch unbestimmt wird. Auf die Annahme la, Sp. $3 \geq \$$, einzugehen, erübrigt sich wohl. Wenn Herr Ludendorff nun meinen sollte, wir hätten die aus dem Diagramm Tafel $\mathrm{X}$ unserer Akademie-Arbeit in die Augen springende Andeutung des von ihm diskutierten systematischen Verhaltens nicht bemerkt, so kann er sich für diese Meinung nicht auf den Inhalt unserer Arbeit berufen. Denn auf Seite $3 \mathrm{t}$ haben wir den wichtigen Punkt des Einflusses der Nullpunktsverschiebung auf die Reduktion

Reste systematischer Fehler diescr Art sind wir allerdings nicht eingetreten:

1. weil sie bei ihrer Kleinheit - man betrachte das Diagramm der Restglieder, Tafel XI - nicht cinmal verbürgt sind,

2. weil wir nicht wissen. ob es sich nicht eventuell sogar um einen reellen Effekt handelt.

3. weil wir, wenn ein systematischer Fehler vorliegen sollte, keine vernünftige Deutung dafür besitzen.

Wir haben uns deshalb mit der allgeneinen Bemerkung über die systematischen Restglieder, S. 34 oben, begnügt, daß, soweit noch systematische Fehler den Messungen anhaften, wir es vorgezogen hătten, sic darin zu belassen und nicht versucht hă̈tten. sie durch die Einführung von un. deutbaren Korrektionen zum Verschwinden zu bringen.

Das Ergebnis der sachlich hinfalligen Utberlegungen von Herrn Ludendorff ist noch dazu nur eine Erniedrigung des Wertes der Lichtablenkung auf einen Betrag, den wit selbst als mit unseren Ergebnissen noch verträglich bezeichnet haben. Es liegt darum jedenfalls kein sachlicher $A$ nla $B$ zu seinen Ausfuhrungen vor.

1) Die FuBnote 3 a, a. O. hebt den logischen Widersinn seinet Reduktionsmethode keineswegs auf.

Potsdam, den 1. Febr, 1932

Astrophys. Observatorium - Einstein.Institut.

\section{Erwiderung auf die vorstehende "Bemerkung".}

Da die Ausführungen in der vorstehenden Bemerkung ein nicht zutreffendes Bild von dem Inhalt meiner Arbeit in $\mathrm{AN} 5848$ geben, so erwidere ich darauf folgendes:

1. Rechnungen, wie die der Herren Autoren, sollen nicht nur oim wesentlichens, sondern ganz exakt sein.

2. Ich habe ausdrücklich betont, daB die Annahme Ib onur als grobe Annäherung oder als rein formal zu bewertene ist. Im übrigen ist es kein nehmen, daß ein systematischer Fehler unbekannten Ursprunges auf der einen Halfite einer Platte im entgegengesetzten Sinne verlăuft als auf der andern.

3. Nirgends habe ich die Zumutung gestellt, die 5 Sterne der Westhalffte einfach fortzulassen. Ich habe nur die ${ }_{13}$ Sterne der Osthallfte zuerst für sich diskutiert und dann die der Westhälfte hinzugezogen.

4. Es erubrigt sich keineswegs, auf die Annahme Ia einzugehen, die ja von dem slogischen Widersinne der Annahme Ib frei ist. Ich behaupte aber heute ebensowenig wie früher, $d a B$ Ia notwendig richtig sei.

5. Gegenuber der Aussage, daß den Herren Autoren das systematische Verhalten der tangentialen Komponenten bekannt gewesen sei, ist der Satz in ihrer Akademie Abhandlung (S. 37) , Die Winkel.... offenbaren die
Besonderheiten, die ihrem Wesen nach, als AusfluB der zufalligen Fehler zu erwarten sinde schwer verstàndlich. Wenn möglich noch schwerer verstindlich ist die Tatsache, daß sie die Erscheinung mit keinem Worte erwähnt auch nicht auf $\mathrm{S}, 31-32$ ), geschweige denn sie diskuticrt haben. Die Gründe, die sie dafür anführen, sind nicht stichhaltig, denn an der Realităt des systematischen Verhaltens für die Osthalfte des Areals kann kein Zweifel bestehen.

6. Von meinen als wachlich hinfallige bezeichneten Ausfuhrungen habe ich demnach kein Wort zurückzunehmen. $\mathrm{Da}$ die Herren Autoren die Ursache des svstematischen Fehlers nicht anzugeben wissen, so bleibt ihr Wert von $E$ (2:24) mit einer starken Unbestimmtheit behaftet. Man wird einstweilen wohl $E=$ etwa r.05 als den plausibelsten aus den Messungen der Herren Autoren folgenden Wert annehmen können.

Wie ich höre, wird demnăchst von anderer Seite eine eingehende Kritik der Abhandlung der Herren Fretundlich, von Klüber und von Brunn erfolgen. Ich werde daher auf dieses Thema nicht mehr zurückkommen.

Potsdam, Astrophysikalisches Observatorium,

1932 Febr. $1_{3}$. H. Ludendorff

Figure 11. Controversy between LUDENDORFF, on the one hand, and FreUNDLICH, V. KLÜBER \& V. BRUNN, on the other, in the Astronomische Nachrichten 244 [1932], No. 5853 , col. $415-416$.

show in 1937 that the accuracy of the results, even from such optimized equipment as FrEUNDLICH used in Sumatra in 1929, "cannot be improved substantially over that reached at the time of the eclipse", ${ }^{31}$ due to the obscuring corona and other unavoidable systematic optical sources of error.

131 "nicht wesentlich über die seinerzeit bei der Finsternis erreichte [Genauigkeit] hinaus steigern läßt”. v. BRUNN \& v. KLÜBER [1937] p. 242. 
But despite all this research at the extreme limits of the contemporary precision instruments technology, Freunderch continued to be convinced that, despite being at odds with EINSTEIN's prediction of the deflection of light, the general tendency of his findings were supported by his very careful determination of the scale values through comparison against the independent ruled scale, as well as by later observations which also tended to yield large values for light deflection at the sun's rim, and thus were generally viable. ${ }^{132}$

\section{Freundlich's Speculations on the Photon-Photon Interaction, and Conclusion}

Thus, since the reanalysis of the earlier data from the expedition of the Lick Observatory of 1922, which was made using the same large-scale reduction of the data and with the best possible elimination of systematic error, also yielded an equally large value, Freunduch began to doubt seriously the complete validity of the general theory of relativity in describing the propagation of light in the proximity of the sun. This suspicion was further strengthened by the equally stubborn problems in detecting the gravitational redshift predicted by EINSTEIN in the solar spectrum. Since the thirties FreundLICH had surmised that the field equations of the general theory of relativity were only approximately correct, that light did not propagate along the geodesic lines of space-time, but rather was forced by an additional interaction onto slightly different paths. In the 1950's this search for possible additional effects led him to the idea, which he pursued up to his death, of a photon-photon interaction, ${ }^{133}$ the effects of which were proportionate to the radiation density $u$ and to the distance $l$ in a radiation field, through which a quantum of light travels. Due to the StefanBoltzmann law which connects the radiation density $u$ to the fourth power of temperature $T$, Freunduich set, for instance, for the redshift: ${ }^{134}$

$$
\frac{\Delta v}{v}=-A \cdot T^{4} \cdot l
$$

He determined the constant $A \simeq 2 \cdot 10^{-29} \mathrm{degr}^{-4} \mathrm{~cm}^{-1}$ from data available to him from the statistics of fixed stars, under the simplifying assumption that the average surface temperature of a fixed-star class could be applied for $T$, and the average radius for $l$, so that then the average observed redshift could be obtained for the fixed-stars of this class. He was encouraged by the fact that he obtained approximately concurring orders of magnitude for the constant $A$, and

132 i.e., MIKhaIlov measured in $1936 E=2^{\prime \prime} .7 \pm 0^{\prime \prime} .3$, v. BIESBROEK [1950] measured in 1947: $E=2^{\prime \prime} .9 \pm 0^{\prime \prime} .3$ (see Table 5 as well as WILL [1989] pp. 79ff.).

133 This is a reciprocal influence of light quanta upon each other.

134 See, e.g., FreundLICH [1953], [1954a-f, [1957], FreundLICH \& Forbes [1956], [1959]. 
that an extension of his law (8) to explain cosmological redshift even seemed feasible, since the dependency of redshift on distance was automatically built into the law (8), whereas approximately 2 degrees Kelvin resulted for the temperature, in order to agree with the then estimate for the Hubble constant. Furthermore, he also hoped to be able to explain with this photon-photon interaction the mysterious limb-center shift in the solar spectrum, which ought to have a much larger effect for solar limb rays than for central ones, purely for geometric reasons. Yet, even this last of a lifetime of attempts by FreundLICH to master the many problems within one unifying assessment failed. Objections were raised from disparate quarters against his arguments - in part against the data he used, in part against other effects implied by his formula (8), for which there was absolutely no evidence. ${ }^{135}$ These new fierce controversies, among others, with Eleanor Margaret and Geoffrey R. Burbidge, William Hunter MCCrea, Dirk ter HaAr, as well as with Max Born brought Freundlich again (and this time permanently) into isolation within his field. ${ }^{136}$ EINSTEIN had at this time lost all interest in experimental tests of his theory. When BorN informed him of FREUNDLICH's latest results on light deflection and gravitational redshift, ${ }^{137}$ EINSTEIN answered:

The verification of the theory is unfortunately much too complicated for me. We're all just poor devils, you know. But Freundlich doesn't impress me one bit. If absolutely no light deflection, no perihelion motion and no line shifts were known, the gravitation equations would still be convincing, because they avoid the inertial system (this ghost, who influences everything, but who in turn does not react to things). It is actually odd that people are usually deaf to the strongest arguments, while they are constantly inclined to overrate precision in measurement. ${ }^{138}$

135 See in this regard, e.g., the comments by Born [1954], BURBIDGE [1954], MCCREA [1954] and TER HARR [1954], as well as by HOPMANN [1954], FERRARI D'OCCHIEPPO [1954] and MELVIN [1955].

${ }^{136}$ See, for example, BATTEN [1985] p. 35 for a description of a heated debate between BORN and FREUNDLICH on the occasion of BORN's farewell lecture in St. Andrews, which culminated in a "fever-pitch of his excitement" and FreundLICH's subsequent heart attack. BORN wrote laconically to EINSTEIN: "Freundlich was, by the way, very ill - coronary thrombosis" ("Freundlich war übrigens sehr krank, HerzArterien-Thrombose"). 20 Jan. 1954, in BORN (Ed.) [1969] p. 286.

${ }^{137}$ See also Born to EINSTEIN, 4 May 1952, BORN (Ed.) [1969] pp. 255f:: "Yesterday Freundlich was here and gave a clear lecture on the state of light deflection by the sun. It really does look as if your formula isn't quite right. It looks even worse for redshift; within the sun's disk it is much smaller, at the rim, larger than the theoretical value. What's going on here? Could this be an indication of non-linearity (scattering of light by light)? Have you considered this?" ("Gestern war Freundlich hier und hat uns einen klaren Vortrag über den Stand der Lichtablenkung durch die Sonne gehalten. Es sieht wirklich so aus, als ob Deine Formel nicht ganz stimmt. Bei der Rotverschiebung sieht es noch schlimmer aus; im Innern der Sonnenscheibe ist sie viel kleiner, am Rande größer als der theoretische Wert. Was ist da los? Kann es eine Andeutung von NichtLinearität (Streuung von Licht durch Licht) sein? Hast Du Dich damit beschäftigt?"

138 "Die Prüfung der Theorie ist leider viel zu schwierig für mich. Der Mensch ist ja 
How different is the EINSTEIN of 1952 from the one of 1911, who had pressed FREUNDLICH so much to do everything within his means to arrive at a verification of his predictions (see Section 3)!

FREUNDLICH, on the contrary, participated in an expedition to observe the solar eclipse in Sweden as late as 1954, in which he was accompanied by two members of the staff of the Astrophysikalisches Observatorium in Potsdam and used instruments of the German Academy of Sciences in Berlin (Deutsche Akademie der Wissenschaften zu Berlin). ${ }^{139}$ In a professional opinion to Dr. JOSEF NAAS, the director of this academy, EINSTEIN aired his doubts about "whether the advancement gained by a new determination [of the deflection of light] justifies the considerable costs of such research", since no significant improvement in measurement precision over earlier observations could be expected from the available instruments. ${ }^{140}$ FREUNDLICH's project nevertheless was supported - unfortunately, also this opportunity to test light deflection anew fell through, due to cloudy conditions at the time of the solar eclipse. Thus FreundLich was denied this last possibility to verify with his own data whether the deflection of light was de facto larger than prognosticated by EINSTEIN for rays of light passing near the sun. FreUNDLICH was not able to witness the later technological improvements in measuring light deflection in a gravitational field, especially in the area of radio-interferometry, nor the appearance of additional quantitative tests of general relativity, for example, through time retardation connected with light deflection. He spent his last days together with his wife, who survived him by many years, in Wiesbaden, after he had received an honorary professorship in 1957 at the Johannes Gutenberg-Universität Mainz. FreundLICH died on the 24th of July, 1964 in Mainz.

In looking over FREUNDLICH's career, it becomes above all apparent that frequently throughout his life he adopted opinions that were at variance with the majority view and actively defended them, unswayed by the disadvantages his professional reputation suffered as a result. At first, as an early supporter of

doch nur ein armes Luder! Der Freundlich aber rührt mich nicht ein bißchen. Wenn überhaupt keine Lichtablenkung, keine Perihelbewegung und keine Linien-Verschiebung bekannt wäre, wären die Gravitationsgleichungen doch überzeugend, weil sie das Inertialsystem vermeiden (dies Gespenst, das auf alles wirkt, auf das aber die Dinge nicht zurückwirken). Es ist eigentlich merkwürdig, daß die Menschen meist taub sind gegenüber den stärksten Argumenten, während sie stets dazu neigen, Meßgenauigkeiten zu überschätzen." EINSTEIN to BORN, 12 May 1952, in BORN (Ed.) [1969] p. 258.

139 See (RAS) Papers 81/2, Minutes of the Joint Eclipse Committee, 14 Nov. 1952, 2 July 1953, 27 Aug. 1954 and 14 Jan. 1955. FREUNDLICH received contributions from the Royal Astronomical Society of 600 and 500 pounds. See also FreUNDLICH [1954]g p. 441, for GrotRIAN's planned participation.

140 "ob der durch eine neue [Lichtablenkungs-]Bestimmung erreichbare Fortschritt die bedeutenden Kosten eine solchen Untersuchung rechtfertigt", zu erwarten sei. (CPAE), call no. 11 195. Cf. also BAADE to PAULI, 6 Feb. 1954 (ETH, provided by courtesy of Dr. KARL V. MEYENN): "Es ist mir ziemlich unerfindlich, weshalb er [Freundlich] herumzieht und Kapital an der Tatsache zu schlagen versucht, daß seine 
Table 5. Comparative overview of the results of various solar eclipse

\begin{tabular}{|c|c|c|c|c|c|c|c|c|c|}
\hline 1 & $\begin{array}{l}2 \\
\text { Observatory } \\
\text { (site) }\end{array}$ & $\begin{array}{l}3 \\
\text { Eclipse }\end{array}$ & $\begin{array}{l}4 \\
\text { Focal } \\
\text { length } f \\
(\mathrm{~cm})\end{array}$ & $\begin{array}{l}5 \\
\text { Aperture } \\
\phi(\mathrm{cm})\end{array}$ & $\begin{array}{l}6 \\
\phi / f\end{array}$ & $\begin{array}{l}7 \\
\text { Instrument } \\
\text { (lens) }\end{array}$ & $\begin{array}{l}8 \\
\text { Field } \\
\text { of plate }\end{array}$ & $\begin{array}{l}9 \\
\text { Number } \\
\text { of plates }\end{array}$ & $\begin{array}{l}10 \\
\text { Exposure } \\
\text { (sec) }\end{array}$ \\
\hline \multirow[t]{2}{*}{1} & $\begin{array}{l}\text { Greenwich } \\
\text { (Brazil) }\end{array}$ & $\begin{array}{l}1919 \\
\text { May } 29\end{array}$ & 570 & 10 & $1: 57$ & $\begin{array}{l}\text { Coelostat } \\
\text { (Double) }\end{array}$ & $2^{\circ} .4 \times 2^{\circ} .0$ & 7 & 28 \\
\hline & & & 343 & 20 & $1: 17$ & $\begin{array}{l}\text { Coelostat } \\
\text { (Double) }\end{array}$ & $2.7 \times 2.7$ & 16 & $5-10$ \\
\hline 2 & $\begin{array}{l}\text { Greenwich } \\
\text { (Principe) }\end{array}$ & $\begin{array}{l}1919 \\
\text { May } 29\end{array}$ & 343 & 20 & $1: 17$ & $\begin{array}{l}\text { Coelostat } \\
\text { (Double) }\end{array}$ & $2.7 \times 2.7$ & 2 & $2-20$ \\
\hline 3 & $\begin{array}{l}\text { Adelaide- } \\
\text { Greenwich } \\
\text { (Australia) }\end{array}$ & $\begin{array}{l}1922 \\
\text { Sept. } 21\end{array}$ & 160 & 7.5 & $1: 21$ & $\begin{array}{l}\text { Astrograph } \\
\text { (Quadruple) }\end{array}$ & $7 \times 8$ & 2 & $20-30$ \\
\hline 4 & $\begin{array}{l}\text { Victoria } \\
\text { (Australia) }\end{array}$ & $\begin{array}{l}1922 \\
\text { Sept. } 21\end{array}$ & 330 & 15 & $1: 22$ & $\begin{array}{l}\text { Astrograph } \\
\text { (Quadruple) }\end{array}$ & - & 2 & 45 \\
\hline 5 & $\begin{array}{l}\text { Lick I } \\
\text { (Australia) }\end{array}$ & $\begin{array}{l}1922 \\
\text { Sept. } 21\end{array}$ & 450 & 12 & $1: 37$ & $\begin{array}{l}\text { Doubl. } \\
\text { Astrograph } \\
\text { (Double) }\end{array}$ & $5 \times 5$ & 4 & $120-125$ \\
\hline 6 & $\begin{array}{l}\text { Lick II } \\
\text { (Australia) }\end{array}$ & $\begin{array}{l}1922 \\
\text { Sept. } 21\end{array}$ & 150 & 10 & $1: 15$ & $\begin{array}{l}\text { Astrograph } \\
\text { (Quadruple) }\end{array}$ & $15 \times 15$ & 6 & $60-102$ \\
\hline 7 & $\begin{array}{l}\text { Potsdam I } \\
\text { (Sumatra) }\end{array}$ & $\begin{array}{l}1929 \\
\text { May } 9\end{array}$ & 850 & 20 & $1: 42$ & $\begin{array}{l}\text { Coelostat } \\
\text { (Double) }\end{array}$ & $3 \times 3$ & 4 & $40-90$ \\
\hline 8 & $\begin{array}{l}\text { Potsdam II } \\
\text { (Sumatra) }\end{array}$ & $\begin{array}{l}1929 \\
\text { May } 9\end{array}$ & 343 & 20 & $1: 17$ & $\begin{array}{l}\text { Astrograph } \\
\text { (Triplet) }\end{array}$ & $7.5 \times 7.5$ & 3 & $14-56$ \\
\hline 9 & $\begin{array}{l}\text { Sternberg } \\
\text { (U.S.S.R.) }\end{array}$ & $\begin{array}{l}1936 \\
\text { June } 19\end{array}$ & 600 & 15 & $1: 40$ & $\begin{array}{l}\text { Astrograph } \\
\text { (Double) }\end{array}$ & $3.5 \times 3.5$ & 2 & $25-35$ \\
\hline 10 & $\begin{array}{l}\text { Sendul } \\
\text { (Japan) }\end{array}$ & $\begin{array}{l}1936 \\
\text { June } 19\end{array}$ & 500 & 20 & $1: 25$ & $\begin{array}{l}\text { Coelostat } \\
\text { (Double) }\end{array}$ & $2.9 \times 2.9$ & 2 & 80 \\
\hline 11 & $\begin{array}{l}\text { Yerkes I } \\
\text { (Brazil) }\end{array}$ & $\begin{array}{l}1947 \\
\text { May } 20\end{array}$ & 609 & 15 & $1: 40$ & $\begin{array}{l}\text { Astrograph } \\
\text { (Triplet) }\end{array}$ & $4 \times 4$ & 1 & 185 \\
\hline 12 & $\begin{array}{l}\text { Yerkes II } \\
\text { (Sudan) }\end{array}$ & $\begin{array}{l}1952 \\
\text { Feb. } 25\end{array}$ & 609 & 15 & $1: 40$ & $\begin{array}{l}\text { Astrograph } \\
\text { (Triplet) }\end{array}$ & $4 \times 4$ & 2 & $60-90$ \\
\hline
\end{tabular}

Einstein, actually even his first apologist within the German circle of astronomers, he became the scapegoat of the conservative and antirelativisticallyminded astronomers of the type of v. SEELIGER, who sought an outlet for their resentment of the revolutionary theorist. Then, when from 1919 onwards the scientific community began increasingly to acknowledge, and even to admire EINSTEIN's relativity theories, FreUndLICH began from 1931 on to express his doubts about the accuracy of this theory, and then to interpret precisely those

Messungen $2^{\prime \prime}, 2$ für die Lichtablenkung ergeben im Gegensatz zum vorausgesagtem Wert und dem von Campbell und Trümpler. Er sollte lieber froh sein, daß bei allen Schwächen sein Wert noch so gut mit dem Campbell-Trümplerschen Werte übereinstimmt." 
expeditions on light deflection at the sun's rim, from v. KLÜBER [1960]

\begin{tabular}{|c|c|c|c|c|c|c|c|}
\hline $\begin{array}{l}11 \\
\text { Limiting } \\
\text { stellar } \\
\text { magnitude }\end{array}$ & $\begin{array}{l}12 \\
\text { Number } \\
\text { of stars }\end{array}$ & $\begin{array}{l}13 \\
r_{\min } \\
\text { (solar } \\
\text { radii } \\
\text { from } \\
\text { center) }\end{array}$ & $\begin{array}{l}14 \\
r_{\max } \\
\text { (solar } \\
\text { radii } \\
\text { from } \\
\text { center) }\end{array}$ & $\begin{array}{l}15 \\
\text { Check- } \\
\text { ficld }\end{array}$ & $\begin{array}{l}16 \\
L\end{array}$ & $\begin{array}{l}17 \\
\text { m.s.e. }\end{array}$ & $\begin{array}{l}18 \\
\text { Reference }\end{array}$ \\
\hline $6(\mathrm{ph})$ & 7 & 2 & 6 & no & $1^{\prime \prime} 98$ & $0^{\prime \prime} 16$ & $\begin{array}{l}\text { DYSON-EDDINGTON } \\
\text { DAVIDSON, } 1920\end{array}$ \\
\hline $6(\mathrm{ph})$ & 11 & 2 & 6 & no & 0.93 & - & \\
\hline $6(\mathrm{ph})$ & 5 & 2 & 6 & no & 1.61 & 0.40 & \\
\hline 8.3 & $11-14$ & 2 & 10 & yes & 1.77 & 0.40 & DODWELL-DAVIDSON, 1924 \\
\hline 9.0 & 18 & 2 & 10 & $\begin{array}{l}\text { not } \\
\text { used }\end{array}$ & $\begin{array}{l}1.75 \\
1.42 \\
2.16\end{array}$ & - & Chant-Young, 1924 \\
\hline $10.5(\mathrm{ph})$ & $62-85$ & 2.1 & 14.5 & yes & 1.72 & 0.15 & CAMPBELL-TRUMPLER, 1923a \\
\hline $10.4(\mathrm{ph})$ & 145 & 2.1 & 42 & yes & 1.82 & 0.20 & CAMPBELL-TRUMPLER. 1928 \\
\hline 8.9 & $17-18$ & 1.5 & 7.5 & yes & 2.24 & 0.10 & $\begin{array}{l}\text { FREUNDLICH-V. KLÜBER- } \\
\text { v. BRUNN, 1931a }\end{array}$ \\
\hline 9.5 & $84-135$ & 4 & 15 & yes & - & - & $\begin{array}{l}\text { FREUNDLICH- } \\
\text { v. KLÜBER- v. BRUNN, } 1933\end{array}$ \\
\hline 9.6 & $16-29$ & 2 & 7.2 & not used & 2.73 & 0.31 & MiKHAILOV, 1940 \\
\hline 8.6 (vis.) & 8 & 4 & 7 & no & 2.13 & 1.15 & Matukuma, $1940 \mathrm{a}$ \\
\hline 10.2 & 51 & 3.3 & 10.2 & not used & 2.01 & 0.27 & VAN BIESBROECK, 1950 \\
\hline 8.6 & $9-11$ & 2.1 & 8.6 & yes & 1.70 & 0.10 & VAN BIESBROECK, 1953. \\
\hline
\end{tabular}

experiments which everywhere were admired as its triumphant verification (light deffection and gravitational redshift) differently from the majority of physicists, astrophysicists and astronomers. Twice his reputation was damaged to such an extent that few professional opportunities remained open to him - his relatively secure occupation as director of the Einstein Institute between 1921 and 1933 should rather be looked upon as a enclave won through bitter struggle in the midst of an, in general, rather hostile environment; and his posts in exile in Istanbul just as later in St. Andrews were rather peripheral ones, in the geographic no less than the professional sense. Thus, the numerous breaks in the otherwise battered and windy course of FREUNDLICH's career, which we have retraced in this study, stem from his peculiar tendency to the contrary. His contributions today are nontheless unjustifiably forgotten. FreundLICH's research exemplarily demonstrates the difficulties involved in verifying a theory factually. In the case of the general theory of relativity, for decades, a constant readjustment and refinement of experimental measurements, components of instruments and theoretical statements took place to describe the very complex processes in and around the sun, which also tapped developments from other areas of technology, physics and astrophysics such as radio interferometry, solar theory (atmosphere models), quantum mechanics (statistics), solid state physics 
and nuclear physics. (Mössbauer effect). Only at the end of the process, in the 1960's and 70's, thus 6 decades after EINSTEIN's publication of relativity theory, and only after FreUnDLICH's death, did it become possible with the latest experimental technology to present a more or less satisfactory 'verification' of the experimental predictions of the general theory of relativity. ${ }^{141}$ The experiments previously held to be decisive for the special theory, such as, for example, the accumulation of mass by electrons, and for the general theory, such as light deflection and redshift measurements in the solar spectrum, proved on the contrary to be completely inadequate, because their accuracy had been overrated, while the systematic errors were too large for the instruments available at that time to surmount. This is true in retrospect also of those experiments that had been accepted by the majority of EINSTEIN's competent contemporaries as key verifications of relativity theory, such as EDdington's and Crommelin's measurements of light deflection in the sun's gravitational field of 1919 or ST. JoHN's results on gravitational redshift of $1923-24 .{ }^{142}$ In this sense, FreUndLICH cannot be blamed entirely for his failure to realize a more precise test of general relativity. On the contrary, despite his overenthusiasm, he also pitilessly searched out the weaknesses of his contemporaries' results for accuracy's sake. His ambitious scheme had just come a few decades too early.

Acknowledgments. I thank Prof. Dr. JOHN D. NORTH (Groningen) and Prof. C. A. TRUeSDell (Baltimore) for their comments on an earlier version, Dr. KARL V. MEYENN for providing me with a copy of BAADE's letter to PAULI, quoted in footnote 140 , Mr. WiNFRIED F. FREUNDLICH (Wiesbaden) for personal reminiscences of his uncle, and my wife ANN for the English translation of this paper.

\section{Abbreviations}

Abh.Berlin: Abhandlungen der Preußischen Akademie der Wissenschaften, Berlin AdA: Annales d'Astrophysique

A.J.: Astronomical Journal

AN: Astronomische Nachrichten

Ann.de Phys: Annales de Physique

An.Phys.: Annalen der Physik

Ann.Sci.: Annals of Science

AP.J.: Astrophysical Journal

C.O.St.A.: Contributions of the Observatory of St. Andrews

CRAS: Comptes Rendus hebdomadaires des Séances de l'Académie des Sciences

DSB: Dictionary of Scientific Biography

FuF: Forschungen und Fortschritte

141 For modern high-precision tests of general relativity theory, see, e.g., WILL [1989] and references therein.

${ }^{142}$ See also EISENSTAEDT [1989] on "The low water-mark of general relativity" between 1925 and 1955. The following overview in Table 5 shows the great variation of the few values obtained for light deflection up to 1960 . 
HSPS: Historical Studies in the Physical Sciences

JRE: Jahrbuch der Radioaktivität und Elektronik

LOB: Lick Observatory Bulletin

LUA: Lund Universitets Årskrift

MNRAS: Monthly Notices of the Royal Astronomical Society

Natw: Die Naturwissenschaften

NYT: New York Times

Obs.: The Observatory

Phil.Mag.: The London, Edinburgh and Dublin Philosophical Magazine

Phys.Rev: Physical Review

Phys.Z.: Physikalische Zeitschrift

PPSL: Proc. Physical Society London

QJRAS: Quarterly Journal of the Royal Astronomical Society

SB.Berlin: Sitzungsberichte der PreuBischen Akademie der Wissenschaften, Berlin

SHPS: Studies in History and Philosophy of Science

VAG: Vierteljahresschrift der Astronomischen Gesellschaft

VDPG: Verhandlungen der deutschen Physikalischen Gesellschaft

ViA: Vistas in Astronomy

VZ: Vossische Zeitung

Wiss.Ann.: Wissenschaftliche Annalen

ZAP: Zeitschrift für Astrophysik

ZfI: Zeitschrift für Instrumentenkunde

\section{Bibliography}

[1] Batten, Alan H. [1985] 'Erwin Finlay-Freundlich, 1885-1964', Journal of the British Astronomical Association 96, pp. 33-35.

[2] v. Biesbroeck, G. [1950] 'The Einstein shift at the eclipse of May 20, 1947, in Brazil', A. J. 55, pp. 49-54.

[3] - [1953] 'The relativity shift at the 1952 eclipse of the sun', A. J. 58, No. 1207, pp. $87-88$.

[4] Blumenthal, Отто [1918] 'Karl Schwarzschild', Jahresberichte der Deutschen Mathematiker-Vereinigung 26, pp. 56-75.

[5] BORN, MAX [1954] 'On the interpretation of Freundlich's redshift formula', PPSL A 67, pp. 193-194 (= reply to FREUNDLICH [1954]b, pp. 192-193).

[6] (Ed.) [1969] Albert Einstein-Hedwig and Max Born Briefwechsel 1916-1955, Munich, Nymphenburger.

[7] TEN Bruggencate, Paul [1955] 'Karl Schwarzschild', in Schwerte, Hans \& SPENGLER, Wilhelm (Eds.) Forscher und Wissenschaftler im heutigen Europa, Oldenburg, pp. 232-239.

[8] v. Brunn, Albert [1930] 'Zur Frage der 'Rotverschiebung' ', Sterne 10, pp. 166-171 (see also FREUNDLICH \& V. BRUNN).

[9] — \& V. KLÜBER, H. [1937] 'Kritische Untersuchung zur Bestimmung der Lichtablenkung durch die Potsdamer Sonnenfinsternisexpedition von 1929', ZAP 14, pp. 242-250.

[10] Burbidge, Eleanor Margaret \& Geoffrey R. [1954] 'On the observational data relating to Freundlich's proposed red-shift law', Phil. Mag (7) 45, pp. 1019-1022 ( = reply to FrEUNDLICH [1954]a, see also TER HAAR [1954], KIR. SCHSTEIN [1954]). 
[11] Campbell, William Wallace [1911]a 'On the motions of the brighter class B stars', LOB 6, pp. 101-124 (No. 195).

[12] — [1911]b 'Some peculiarities in the motion of stars', ibid., pp. 125-135.

[13] [1914] 'Note on evidences of rapid convection in stellar atmospheres', LOB 8, No. 257, pp. 82.

[14] Campbell, W. W. \& Trumpler, R. J. [1923/24] 'Observations on the deflection of light in passing through the sun's gravitational field', LOB 11, pp. 41-54 (No. 346).

[15] — [1928] Observations made with a pair of five-foot cameras on the light deflections in the sun's gravitational field at the total solar eclipse of Sept. 21, 1922', LOB 13, pp. 130-160 (No. 397).

[16] Chant, C. A., \& Young, R. K. [1924] Evidence of the bending of the rays of light on passing the sun, obtained by the Canadian expedition to observe the Australian eclipse', Publications of the Dominion Astrophysical Observatory 2, No. 15 , pp. 275-285 and plates.

[17] ClarK, Ronald W. [1973] Albert Einstein. Leben und Werk, Munich, Heyne.

[18] CourvoIsIER, Leo [1920] 'Jährliche Refraktion und Sonnenfinsternisaufnahmen 1919', AN 211, No. 5056, cols. 705-312.

[19] - [1932] 'Sonnenfinsternis-Aufnabhmen 1919, 1922, 1929 und jährliche Refraktion', $A N$ 244, No. 5854, col. 275-288 (= comm. on FrEUNDLICH, V. KLÜBER \& V. BRUNN [1932]b).

[20] Crelinsten, Jeffrey Michael [1981] The Reception of Einstein's General Theory of Relativity among American Astronomers 1910-1930, Diss., Université de Montreal.

[21] _ [1983] 'William Wallace Campbell and the "Einstein Problem": An observational astronomer confronts the theory of relativity", HSPS 14, pp. 1-92.

[22] Cunningham, Ebenezer [1920]: Review of Freundlich [1916]c, Nature 105, pp. $350-351$.

[23] DANJon, A. [1932] 'Le déplacement apparent des étoiles autour du soleil éclipsé', Le Journal de Physique (7) 3, pp. 281-301 (short version in CRAS 194, pp. 252-254).

[24] Diecke, Sally H. [1975] 'Schwarzschild, Karl', DSB 12, pp. 247-253.

[25] Dodwell, G. F. \& Davidson, C. R. [1924] 'Determination of the deflection of light by the sun's gravitational field from observations made at Cordillo Downs, South Australia, during the total eclipse of 1922', MNRAS 84, pp. $150-162$.

[26] Dyson, Frank WatSon [1921] 'Karl Hermann Struve', MNRAS 81, pp. $270-272$.

[27] — [1939] 'William Wallace Campbel1 1862-1938', Obituary Notices of Fellows of the Royal Society 2, pp. 613-619.

[28] \& Eddington, A. S. \& Davidson, C. [1920] 'A determination of the deflection of light of the sun's gravitational field from observations made at the total eclipse of May 29, 1919', Philosophical Transactions of the Royal Society, London, A 220, pp. 291-334 (= Review of FREUNDLICH [1920]e).

[29] Dyson, F. W. \& Woolley, R. v. D. R. [1937] Eclipses of the Sun and Moon, Oxford, Clarendon, especially chap. VII on light deflection.

[30] EARMAN, JOHN \& GLYMOUR, ClARK [1980]a 'The gravitational redshift as a test of general relativity: history and analysis', SHPS 11, pp. 251-278.

[31] [1980]b 'Relativity and eclipses: the British eclipse expeditions of 1919 and their predecessors', HSPS 11, pp. 49-85. 
[32] EdDINGTON, ARTHUR STANLEY [1925] Relativitätstheorie in mathematischer Behandlung, Berlin, Springer.

[33] EINSTEIN, AlbERT [1907] 'Über das Relativitätsprinzip und die aus demselben gezogenen Folgerungen', JRE 4, pp. 411-462.

[34] - [1908] Corrections of [1907], ibid. 5, pp. 98-99.

[35] - [1911] 'Über den Einfluß der Schwerkraft auf die Ausbreitung des Lichtes', a) Ann. Phys. (4) 35, pp. 898-908; b) in Sommerfeld (Ed.) [1923], pp. 72-80.

[36] - [1912]a 'Lichtgeschwindigkeit und Statik des Gravitationsfeldes', Ann. Phys. 38, pp. 355-369.

[37] - - [1912]b 'Zur Theorie des statischen Gravitationsfeldes', ibid., pp. 443-458.

[38] - [1915]a 'Zur allgemeinen Relativitätstheorie', SB. Berlin 4 Nov. 1915, pp. 778-786 as well as 'Nachtrag', ibid., pp. 799-801.

[39] — - [1915]b 'Erklärung der Perihelbewegung des Merkur aus der allgemeinen Relativitätstheorie", ibid., pp. 831-839.

[40] - [1915]c 'Die Feldgleichungen der Gravitation', ibid., pp. 844-847.

[41] - [1916]a 'Gedächtnisrede auf Karl Schwarzschild', SB. Berlin, pp. 768-770.

[42] - [1916]b 'Die Grundlagen der allgemeinen Relativitätstheorie', Ann. Phys. (4) 49, pp. 769-811; c) reprinted in SOMMERFELD [1923]a, pp. 81-124.

[43] - [1917] Über die spezielle und die allgemeine Relativitätstheorie, Braunschweig, Vieweg; a) 1st ed. 1917 ( = Tagesfragen aus den Gebieten der Naturwissenschaften und der Technik, Issue 38); b) 10th ed. 1920; c) Reprint of the 21st ed. 1969; 1979; d) in Engl. transl. as: Relativity, the Special and General Theory, New York, Crown, 1961; e) in French transl. by J. RouviÉRE: La théorie de la relativité restreinte et généralisée à la portée de tout le monde, Paris, Gauthier-Villars, 1921.

[44] — [1917]f 'Kosmologische Betrachtungen zur Allgemeinen Relativitätstheorie', SB. Berlin, Feb. 8, 1917, pp. 142-152 (cf. Natw. 7, p. 232); g) in SOMMERFELD (Ed.) [1923] pp. 130-139.

[45] [1920] Relativity, New York, Holt (see also Review by HARRow [1921]).

[46] EISENSTAEDT, JEAN [1989] 'The low water-mark of general relativity, 1925-1955', in: DON HOWARD \& JOHN STACHEL (Ed.) [1989], pp. 277-292.

[47] FABry, Charles \& Buisson, Henri [1910] 'Application de la méthode interférentielle à la mesure de très petits déplacements de raies, comparison du spectre solaire avec le spectre d'arc du fer. Comparaison du centre et du bord du soleil', A. P. J. 31, pp. 97-119.

[48] FERRARI D'OCChIEPPO, K. [1954] [A possible test for Freundlich's red-shift], Obs. 74, pp. $169-170$.

[49] Forbes, ERIC Gray [1963] 'A history of the solar red shift problem', Ann. Sci. 17, pp. $129-164$.

[50] — [1972] 'Freundlich, Erwin Finlay', DSB 5, pp. 181-184.

[51] Freundlich, ERwiN F. (later: Erwin Finlay-Freundlich) [1911]: Analytische Funktionen mit beliebig vorgeschriebenem unendlich vielblättrigem Existenzbereiche, Diss. Univ. Göttingen, under the supervision of Prof. FELIX KLEIN.

[52] — [1913] 'Über einen Versuch, die von Einstein vermutete Ablenkung des Lichtes in Gravitationsfeldern zu prüfen' $A N$ 193, No. 4628, col. 369-372.

[53] [1914]a 'Über die Verschiebung der Sonnenlinien nach dem roten Ende auf Grund der Hypothesen von Einstein und Nordström', Phys. Z. 15, pp. 369-371.

[54] [1914]b 'Positionen und Eigenbewegungen von 154 Sternen', $A N$ 197, No. 4722, col. 297-302.

[55] - [1914]c 'Bedeckung des Sterns BD + 12.2138 durch den Mond während der totalen Sonnenfinsternis am 21. August 1914', $A N$ 197, No. 4724, col. 335-336. 
[56] — - [1914]d 'Über die Verschiebung der Sonnenlinien nach dem roten Ende auf Grund der Äquivalenzhypothese von Einstein', $A N$ 198, No. 4742, col. 265-270.

[57] — [1915] 'Ueber die Erklärung der Anomalien im Planetensystem durch die Gravitationswirkung interplanetarer Massen', $A N$ 201, No. 4803, col. 49-56 ( = comm. on v. SEelger [1906]; see also v. SEELIGER'S reply [1915]).

[58] — [1915/16] 'Über die Gravitationsverschiebung der Spektrallinien bei Fixsternen', a) short version in Phys. Z. 16, pp. 115-117; b) $A N$ 202, No. 4826, col. 17-24 (see also the cont. in: FREUNDLICH [1916]d, [1919]c).

[59] — [1916] Die Grundlagen der Einsteinschen Gravitationstheorie, a) Natw. 4, pp. 363-372, 386-392; b) in book form: Berlin, Springer; c) in Engl. transl. by Brose: Cambridge, Cambridge Univ. Press, 1920; see also Cunningham [1920], Harrow [1921]); d) in French transl., Paris, Gauthier-Villars, 1922.

[60] [1916]d 'Bemerkungen zu meinem Aufsatz in A. N. 4826', AN 202, col. 147-148 ( = cont. of FrEUNDLich [1915/16]b.).

[61] — [1917] 'Die Einsteinsche Gravitationstheorie der allgemeinen Relativitätstheorie zu den Hypothesen der klassischen Mechanik', VAG 52, pp. 129-151.

[62] _ [1919]a 'Albert Einstein. Zum Siege seiner Relativitätstheorie', VZ, Nov. 30, suppl.

[63] — [1919]b 'Zur Prüfung der allgemeinen Relativitätstheorie', Natw. 7, pp. 629-636 as well as 'Bemerkungen', ibid., p. 696.

[64] — [1919]c 'Ueber die Gravitationsverschiebung der Spektrallinien bei Fixsternen. II. Mitteilung', Phys. Z. 20, pp. 561-570 (= cont. of FreUndLrCH $[1915 / 16] \mathrm{a})$.

[65] — [1920] 'Die Entwicklung des physikalischen Weltbildes bis zur allgemeinen Relativitätstheorie', a) in: Die weißen Blätter 7, pp. 174-191; b) in: Sitzungsberichte des Vereins zur Forderung des Gewerbefleißes 99, March 1, pp. $45-59$ (with discussion; see also the reply by GLASER [1920]d, ibid., issue 6).

[66] — [1920]c Relativitätstheorie; drei Vorträge (gehalten auf Einladung der Badischen Anilin- and Soda-Fabrik in Ludwigshafen), ca. 1920; d) in Engl. transl.: The Theory of Relativity: Three Lectures for Chemists, with introduction by V. HALDANE, New York, Dutton.

[67] — [1920]e 'Ein Bericht der englischen Sonnenfinsternisexpedition über die Ablenkung des Lichtes im Gravitationsfelde der Sonne', Natw. 8, pp. 667-673 (= Review by DYSON et al. [1920]).

[68] _ [1923]a 'Üeber die Beobachtung der Lichtablenkung während der totalen Sonnenfinsternis am 21. Sept. 1922', Natw. 11, pp. 762-765.

[69] - [1923]b 'Holländisch-Deutsche Sonnenfinsternis nach Christmas Island', AN 218, col. 13-16.

[70] [1929]a 'Die totale Sonnenfinsternis am 9. Mai. Keine endgültigen Resultate', Berliner Tageblatt 58, Thurs., 1 Aug., No. 358, 1. suppl., p. 1.

[71] [- [ [1929]b 'Theory supported, Einstein declares. Observers in Sumatra cable him check of star's rays near eclipse was good', NYT 11 May 1929, p. 21, col. 6.

[72] — [1930]a 'Bericht über die Potsdamer Sonnenfinsternis-Expedition nach Tokengon-Nordsumatra 1929', Natw. 18, pp. 313-323.

[73] - [1930]b 'Heutiger Stand des Nachweises der relativistischen Rotverschiebung der Fraunhoferschen Linien', Natw, 18, pp. 513-519 (see also announcement in $V D P G 11, \mathrm{p}, 10)$.

[74] _ _ [1931] 'Über die Ablenkung des Lichtes im Schwerefeld der Sonne', FuF 21, pp. 292-293 (also mentioned in $S B$. Berlin, math. phys. class, 1931, p. 317). 
[74a] — - [1932] 'Über Probleme der Astrophotographie', in: Berichte über den VIII. Internationalen Kongress für wissenschaftliche und angewandte Photographie, Dresden, 1931, Leipzig, Barth, pp. 296-304.

[75] - [1950] 'On the measurement of the relativistic light deflection', A. J. 55, pp. $245-247$ (= reply to v. BIESBROEK [1950]; see also his reply, ibid., p. 247).

[76] [-] [1952]a 'Über den gegenwärtigen Stand der Prüfung der allgemeinen Relativitätstheorie', Sterne 28, pp. 220-222 (reviewed by E. \& R. AHNERT).

[77] — [1952]b 'Der gegenwärtige Stand der Prüfungen der allgemeinen Relativitätstheorie', Wiss. Ann. 1, pp. 35-42.

[78] — [1953] 'Über die Rotverschiebung der Spektrallinien', NAWG (IIa) No. 7, pp. 96-102 (also as C. O. St. A. 4; see also reply by BORN [1954]).

[79] [1954] 'Red shifts in the spectra of celestial bodies', a) Phil. Mag. (7) 45, pp. 303-319; b) short version in: PPSL A67, pp. 192-193; c) summary in Phys. Rev. (2) 95, p. 654. d) as C. O. St. A. 5 (see also replies by MCCREA [1954] and TER HAAR [1954]).

[80] [1954]e 'The general red shift of spectral lines in the spectra of celestial bodies', LUA N. F. 50, p. 106.

[81] — [1954]f 'Über Rotverschiebungen der Spektrallinien kosmischer Lichtquellen', FuF 28, pp. 353-357.

[82] — [1954]g 'Zum Gedächtnis. Prof. Dr. phil. Walter Grotrian, ordentl. Mitglied der Deutschen Akademie der Wissenschaften zu Berlin', Wiss. Ann. 3, pp. 439-441.

[83] [1955]a 'On the empirical foundation of the general theory of relativity', ViA 1, pp. 239-246.

[84] — [1955]b 'Wird Einsteins Voraussage in Ceylon bestätigt werden?', Neue Zeitung, Sun., 9 Jan. 1955, No. 7, p. 16, col. 1-5.

[85] — [1957] 'Du déplacement général vers le rouge des raies du spectre solaire', Ann. de Phys. (13) 2, pp. 765-777.

[86] [1959] 'The empirical foundation of the general theory of relativity', Scientia 94 (Annus 53), pp. 181-187.

[87] [1960] 'Der Nachweis der Schwere des Lichtes', Natw. 47, pp. 123-127.

[88] [1961] 'Über eine allgemeine Rotverschiebung der Fraunhoferschen Linien', Natw. 48, pp. 709-711.

[89] Freundlich, E. F. \& BrunN, A. v. [1933] 'Über die Theorie des Versuchs der Bestimmung der Lichtablenkung im Schwerefeld der Sonne', ZAP 6, pp. 218-235.

[90] Freundlich, E. F. BRunN, A. v. \& BRÜCK, H. [1930] 'Über den Verlauf der Wellenlängen der Fraunhoferschen Linien längs der Sonnenoberfläche', $Z A P$ 1, pp. $43-57$.

[91] Freundlich, E.. \& Forbes, E. G. [1956] 'On the red shift of solar lines', AdA 19, I: pp. $183-198$, II: $215-222$.

[92] - [1959] ibid., III., AdA 22, pp. 727-732.

[93] Freundlich, E. F. \& GleissberG, W. [1935] 'Zur Frage der Entartung der Ausgleichung in dem Problem der Bestimmung der Lichtablenkung im Schwerefeld der Sonne', Publications of the Istanbul University Observatory, N.S. 1, issue 2, pp. 44-49.

[94] Freundlich, E. F. \& HerrmanN, W. [1931] 'Beschreibung eines großen Plattenmeßapparates',. ZfI 51, pp. 582-586.

[95] Freundlich, E. F. KLÜber, H. v. \& BrunN, A.v. [1931]a 'Ergebnisse der Potsdamer Expedition zur Beobachtung der Sonnenfinsternis von 1929, Mai 9, in 
Takengon (Nordsumatra). 5. Mitteilung: Über die Ablenkung des Lichtes im Schwerefeld der Sonne', ZAP 3, pp. 171-198.

[96] - [1931]b 'Die Ablenkung des Lichtes im Schwerefeld der Sonne', Abh. Berlin, No. 1, pp. 1-61 and plates.

[97] - [1932]a 'Bemerkung zu Herrn Trümplers Kritik', ZAP 4, pp. 221-223 ( = reply to TRÜMPLER [1932]b).

[98] — [1932]b 'Bemerkung zu Herrn Ludendorffs Ausführungen in No. 5848 dieser Zeitschirft', $A N$ 244, No. 5853, col. 415 (= reply to LUDENDORFF [1932]a).

[99] _ [1933] 'Weitere Untersuchungen über die Bestimmung der Lichtablenkung im Schwerefeld der Sonne', Annalen van de Bosscha-Sterrenwacht Lembang 5, pp. B1-B64.

[100] Freundlich, E. F. \& LedermanN, W. [1994] 'The problem of the accurate determination of the relativistic light deflection', MNRAS 104, pp. 40-47.

[101] FREUNDLICH, E. F. \& PAHLEN, E. VAN DER [1923] 'Untersuchung des K-Effektes auf Grund des Katalogs von Radialgeschwindigkeiten von J. Voute', $A N$ 218, No. 5529/30, col. 369-400.

[102] Glaser, Ludwig C. [1920] Bemerkungen zu dem im Verein zur Beförderung des Gewerbefleißes am 1. März 1920 von Herrn Dr. Freundlich gehaltenen Vortrage "Die Entwicklung des physikalischen Weltbildes bis zur allgemeinen Relativitätstheorie", Sitzungsberichte des Vereins zur Beförderung des Gewerbefleißes 99, issue 6, pp. 105-106.

[103] Grotrian, WaLter [1952] '30 Jahre Forschungsarbeit im Einsteinturm in Potsdam', Wiss. Ann. 1, pp. 79-93.

[104] HAAR, DIRK TER [1954] 'On some more remarks on Freundlich's red-shift', Phil. Mag. (7) 45, pp. 1023-1024 (= comm. on FREUNDLICH [1954]a and MCCREA [1954]; see also BURBRIDGE [1954], KIRSCHSTEIN [1954]).

[105] HaRrow, BENJAMIN [1921] Review of FrEUNDLICH [1916]c, EINSTEIn [1920], NYT 17 April, Sect. III. p. 3, col. 1-5 and p. 30.

[106] HeNTSCHEL, KLAUS [1990] Interpretationen und Fehlinterpretationen der speziellen und allgemeinen Relativitätstheorie durch Zeitgenossen Albert Einsteins, Basel et al., Birkhäuser, 1990 (= Science Networks, Vol. 6).

[107] — [1991] 'Julius und die anomale Dispersion - eine Fallstudie zu einer gescheiterten Theorie', Studien aus dem Philosophischen Seminar, series 3, issue 6 (192 pp.).

[108] [1992]a 'Grebe/Bachems photometrische Analyse der Linienprofile und die Gravitations-Rotverschiebung: 1919-1922', Ann. Sci. 49, pp. 21-46.

[109] [1992]b Der Einstein-Turm, Berlin, Heidelberg and New York, Spektrum, 1992.

[110] - [1992]c 'Einstein's attitude towards experiments', SHPS 23, pp. 593-624.

[111] - [1993]a 'Die Konversion von St. John-eine Fallstudie zum Wechselspiel von Theorie und Experiment', to appear in Science in Context 6, 1993.

[112] _ [1993]b 'The Discovery of the Redshift of Solar Spectral Lines by Rowland and Jewell in Baltimore around 1890', to appear in HSPS 23, 2, 1993.

[113] HERMANn, ARMin (Ed.) [1968] Albert Einstein/Arnold Sommerfeld Briefwechsel, Basel and Stuttgart, Schwabe.

[114] Herrmann, W. \& Freundlich, E. F. [1931] 'Beschreibung eines großen Plattenmeßapparates', ZfI 51, pp. 582-586.

[115] Hertzsprung, EJNAR [1917] 'Karl Schwarzschild', AP. J. 45, pp. 285-292.

[116] Hetherington, Norris, S. [1982] 'Philosophical values and observations in Edwin Hubble's choice of a model of the universe', HSPS 13, pp. 41-67. 
[117] Hoffmann, Dieter [1991] 'Erwin Finlay-Freundlich (1885-1964) und die Profilierung der astrophysikalisch-astronomischen Forschung in der Tschechoslowakei', Zbornik Cesdef '91, pp. 137-151.

[118] HOPMANN, JOSEF [1954] 'A possible test for Freundlich's redshift', Obs. 74, p. 169.

[119] HowARD, DON \& STACHEL, JOHN (Eds.) [1989] Einstein and the History of General Relativity, Birkhäuser, Basel et al. (=Einstein Studies, 1).

[120] JACKSON, J. [1931] 'The deflection of light in the sun's gravitational field', Obs. 54, pp. 292-296 (= critique of FrEUNDLICH, v. KLÜBER \& V. BRUNN [1931]).

[120a] Kienle, Hans [1925] 'Hugo von Seeliger', Natw. 13, pp. 613-619.

[121] Kirschstein, G. [1954] 'Zur Rotverschiebung der Sternspektren', PB 10, p. 376 ( = comm. to FREUNDLICH [1954] \& TER HAAR [1954]).

[122] Kirsten, Christa \& Treder, Hans-Jürgen (Ed.) [1979] Albert Einstein in Berlin 1913-1933, Berlin Akademie-Verlag, 2 Vols.

[123] Klein, Martin J., Kox, A. J., Renn, JÜrgen \& Schulmann, RoberT (Eds.) [1993] The Collected Papers of Albert Einstein, Vol. 5: Correspondence 1902-1914, Princeton Univ. Press.

[124] KLÜBER, HARALD v. [1926] 'Die Deutsch-Niederländisch-Indische Sonnenfinsternis-Expedition nach Sumatra 1925/26', Sterne 6, pp. 157-164.

[125] — [1929] 'Ausfahrt zur Sonnenfinsternis', Sterne 9, pp. 85-89.

[126] [1931] 'Ergebnisse der Potsdamer Sonnenfinsternisexpedition 1929, Mai 9. Photographische Photometrie der Sonnenkorona', ZAP a) 2, pp. $289-328$ (2nd communication) or b) 3, pp. 142-162 (4th communication).

[127] - [1931]c 'Die astronomische Nachprüfung der Lichtablenkung im Schwerefeld der Sonne', Sterne 11, pp. 141-155.

[128] — [1932] 'Über eine Horizontalkamera mit Präzisions-Coelostaten für astronomische Beobachtungen', ZfI 52, pp. 381-393.

[129] - [1955] 'Die Sonnenfinsternis vom 30. Juni', Natw. 42, pp. 3-8.

$[130]-[1960]$ 'The determination of Einstein's light-deflection in the gravitational field of the sun', ViA 3, pp. 47-77.

[131] — [1965] 'Erwin Finlay-Freundlich †', a) $A N$ 288, pp. 281-286; b) short version in QJRAS 6, pp. 82-84.

[132] Kopal, ZDENĚK [1964] 'Prof. E. F. Freundlich', Nature 204, pp. 727-728.

[133] LUDENDORFF, HANS [1916] 'Bemerkungen über die Radialgeschwindigkeiten der Helium-Sterne', AN 202, No. 4829, col. 75-84 (= reply to FREUNDLICH [1915], see also V. SEELIGER [1916]).

[134] — [1920]a 'Weitere Untersuchungen über die Massen der spektroskopischen Doppelsterne', $A N$ 211, No. 5046, col. 105-120.

[135] - [1920]b 'Über die Verschiebung der Emissionslinien bei den Mira-Sternen', AN 212, No. 5087, col. 483-484.

[136] - - [1923/24] 'Vorläufiger Bericht über die deutsche Sonnenfinsternis-Expedition nach Mexiko', $A N$ 220, pp. 77-78.

[137] — [1932]a 'Über die Ablenkung des Lichtes im Schwerefeld der Sonne', AN 244 No. 5848, cols. 321-330 (see also reply by FREUNDLICH, V. KLÜBER \& v. BRUNN [1932]b and LUDENDORFF's reply [1932]b).

[138] - [1932]b 'Erwiderung auf die vorstehende Bemerkung', AN 244, No. 5853, col. 415 ( = reply to FREUNDLICH, V. KLÜBER \& V. BRUNN [1932]b).

[139] Mattig, W. [1956] 'Die Lichtablenkung im Schwerefeld der Sonne. Bericht über die Sonnenfinsternisexpeditionen 1954 und $1955^{\prime}$ Die Sterne 32, pp. $177-188$. 
[140] MCCrEa, William Hunter [1954] 'Astrophysical considerations regarding Freundlich's red-shift' Phil. Mag. (7) 45, pp. 1010-1018 (=comm. on FreUNDLICH [1954]; see also TER HAAR [1954]).

[141] Melvin, M. A. [1955] 'Freundlich's red-shift formula', Phys. Rev. (2) 98, pp. $884-887$.

[142] MEYER, FR. [1930] 'Über die Entwicklung der astronomischen Instrumente im Zeisswerke Jena' ZfI 50, pp. 58-99.

[143] Mikhailov, A. A. [1940] 'Measurement of the deflection of light by the sun's gravitational field during the eclipse of June 19, 1936', Doklady Akademii Nauk. USSR 29, pp. 189-190.

[144] [1959] 'The deflection of light by the gravitational field of the sun', MNRAS 119, pp. 593-608.

[145] Moyer, DONALD [1979] 'Revolutions in science: the 1919 eclipse test of general relativity', in: ARNOLd Perlmutter \& L. F. SCOTT (Eds.) On the Path of Albert Einstein, New York, Plenum, pp. 55-101.

[146] NORTH, JoHn D. [1965] The Measure of the Universe. A History of Modern Cosmology, Oxford, Oxford Univ. Press (Reprint New York, Dover, 1990).

[147] OpPenheIM, S. [1923] 'Karl Schwarzschild, zur 50. Wiederkehr seines Geburtstages', VAG 58, pp. 191-209.

[148] Pais, ABraham [1982]a) Subtle is the Lord-the science and the life of Albert Einstein, Oxford et al. Oxford Univ. Press; b) in German transl. Raffiniert ist der Herrgott. Eine wissenschaftliche Biographie, Braunschweig, Vieweg, 1986.

[149] PERrine, C. D. [1923] 'Contribution to the history of attempts to test the theory of relativity by means of astronomical observations', $A N$ 219, No. 5249, col. 281-284.

[150] Pyenson, Lewis [1974] The Goettingen reception of Einstein's General Theory of Relativity, Johns Hopkins Univ. Press, Baltimore (= Ph.D. thesis).

[151] — [1985] The Young Einstein. The Advent of Relativity, Bristol, Hilger.

[152] ROSS, FRANK E. [1920] 'Image contraction and distortion on photographic plates A.P. J. 52, pp. 98-109.

[153] Rowe, David E. [1989] 'Klein, Hilbert, and the Göttingen mathematical tradition', Osiris 5, pp. 186-213.

[154] Seeliger, Hugo v. [1906] 'Das Zodiakallicht und die empirischen Glieder in der Bewegung der innern [sic] Planeten', SB. München 36, pp. 595-622 (see also summary, ibid., p. 594 as well as FreUNDLICH [1915] and v. SEELIGER's reply [1915]).

[155] [1915] 'Über die Anomalien in der Bewegung der innern Planeten', $A N$ 201, col. 273-280 ( = reply to FREUNDLICH [1915]a.).

[156] - [1916] 'Über die Gravitationswirkung auf die Spektrallinien', AN 202, No. 4829, col. 83-86.

[157] Sigurdsson, Skuli [1991] Hermann Weyl, Mathematics and Physics, 1900-1927, Ph.D. thesis, Harvard Univ.

[158] Sommerfeld, ARNold [1916] 'Karl Schwarzschild', Natw. 4, pp. 453-457.

[159] - (Ed.) [1923] of a) LoRentz, H. A. Einstein, A. Minkowski, H.: Das Relativitätsprinzip, Teubner, 5th ed.; b) 7th reprint ed., 1974.

[160] STACHEL, JOHN [1986] 'Eddington and Einstein', in: E. Ullmann-Margalit (Ed.) The Prism of Science, Dordrecht, Reidel, pp. 225-250.

[161] ToBIES, RENATE [1981] Felix Klein (= Biographien hervorragender Naturwissenschaftler, Techniker und Mediziner, Vol. 50), Leipzig, Teubner. 
[162] Treder, Hans-JÜRgen [1974] 'Karl Schwarzschild und die Wechselbeziehungen zwischen Astronomie und Physik', Die Sterne 50, pp. 13-19.

[163] TrüMPLer, ROBERT J. [1932]a 'The deflection of light in the sun's gravitational field', Publications of the Astronomical Society of the Pacific 44, pp. $167-173$.

[164] _ _ [1932]b 'Die Ablenkung des Lichtes im Schwerefeld der Sonne', ZAP 4, pp. 208-220 ( = comm. on FreUNDLICH, v. KLÜBER \& v. BRUNN [1931]a; see also their reply [1932]a).

[165] — \& WeAver, H. F. [1953] Statistical Astronomy, Berkeley, University of California Press.

[166] Will, Clifford M. [1989] Und Einstein hatte doch Recht, Berlin, Heidelberg, New York, Springer.

Institut für Wissenschaftsgeschichte Universität Göttingen

Humboldtallee 11

D-37073 Göttingen

(Received December 24, 1992) 